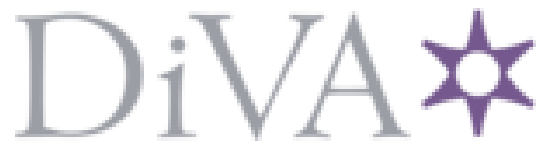

http://www.diva-portal.org

\title{
Postprint
}

This is the accepted version of a paper published in Small Business Economics. This paper has been peer-reviewed but does not include the final publisher proof-corrections or journal pagination.

Citation for the original published paper (version of record):

Braunerhjelm, P., Thuli, P., Ding, D. (2017)

The knowledge spillover theory of intrapreneurship.

Small Business Economics

Access to the published version may require subscription.

N.B. When citing this work, cite the original published paper.

Permanent link to this version:

http://urn.kb.se/resolve?urn=urn:nbn:se:kth:diva-219914 


\section{The knowledge spillover theory of intrapreneurship}

\section{Pontus Braunerhjelm, Ding Ding \& Per Thulin}

Small Business Economics

An Entrepreneurship Journal

ISSN 0921-898X

Small Bus Econ

DOI 10.1007/s11187-017-9928-9

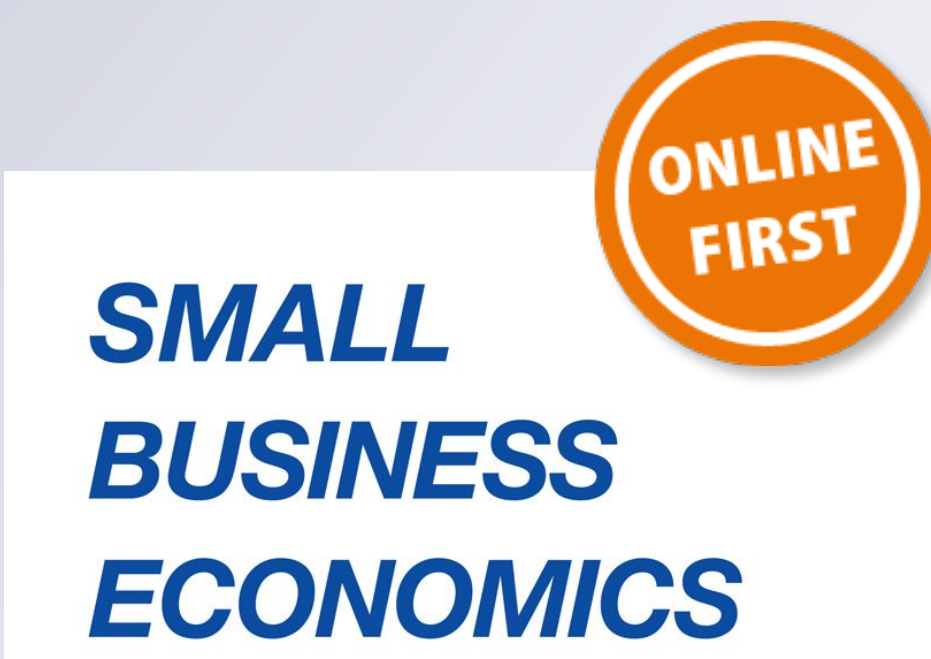

An Entrepreneurship Journal

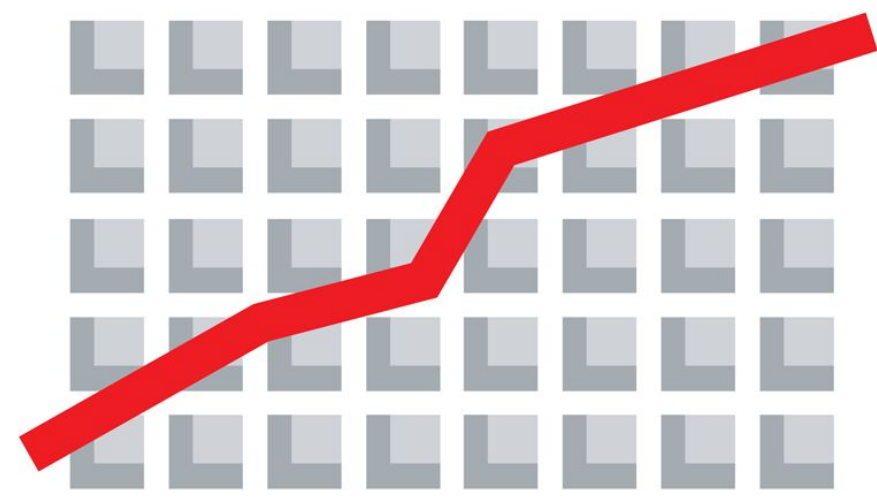

Editors: Zoltan J. Acs and David B. Audretsch

Volume 32 No. 4 April 2009

ISSN 0921-898X

帡 Springer 
Your article is published under the Creative Commons Attribution license which allows users to read, copy, distribute and make derivative works, as long as the author of the original work is cited. You may selfarchive this article on your own website, an institutional repository or funder's repository and make it publicly available immediately. 


\title{
The knowledge spillover theory of intrapreneurship
}

\author{
Pontus Braunerhjelm • Ding Ding • Per Thulin $\mathbb{D}$
}

Accepted: 30 August 2017

(C) The Author(s) 2017. This article is an open access publication

\begin{abstract}
Introducing the Knowledge Spillover Theory of Intrapreneurship, we examine how labour mobility impacts innovation distributed by firm size. A matched employer-employee dataset, pooled with firm-level patent application data, is implemented in the analysis. We provide new evidence that knowledge workers' mobility has a positive and strongly significant impact on all firms' innovation output, measured as patent applications. The patterns and effects do however differ between large and small firms. More precisely, for small firms, intraregional mobility of knowledge workers who have previously worked in a patenting firm (the learning-by-hiring effect) is shown to be statistically and economically highly significant, whereas only limited impact could be detected for firms losing knowledge workers (the learning-by-diaspora effect).
\end{abstract}

Keywords Labour mobility - Knowledge diffusion . Innovation $\cdot$ Social networks

JEL classification $\mathrm{J} 24 \cdot \mathrm{O} 31 \cdot \mathrm{R} 23$

\footnotetext{
P. Braunerhjelm $(\bowtie) \cdot$ D. Ding $\cdot$ P. Thulin

Division of Entrepreneurship and Innovation, KTH Royal Institute of Technology, INDEK, SE100 44 Stockholm, Sweden e-mail: pontus.braunerhjelm@indek.kth.se

P. Braunerhjelm • P. Thulin

The Swedish Entrepreneurship Forum, Grevgatan 34, 114

53 Stockholm, Sweden
}

\section{Introduction}

According to the Knowledge Spillover Theory of Entrepreneurship (KSTE), start-ups are one way of diffusing and converting knowledge into societal utility (Acs et al. 2009). The underlying mechanism refers to innovation in the Schumpeterian sense, realized by exploiting opportunities originating in knowledge overlooked or neglected by incumbents. A parallel mechanism, not addressed in the original version of the KSTE, has to do with labour mobility. More precisely, R\&D workers who move between firms can be expected to diffuse knowledge and to improve the matching of individuals' heterogenous knowledge, thereby generating more of innovations. We argue that labour mobility associated with engagement in innovative activities can be defined as a decisive factor in promoting intrapreneurship, which complements regular entrepreneurship in bringing forth innovations. Hence, in the current analysis, we will merge insights from the fields of labour market economics, entrepreneurship and innovation to investigate how mobility influences innovation across firms of different size.

There is an overwhelming and convincing literature concluding that new and small firms play a disproportionately large role in forwarding radical innovations. The reasons are allotted a number of factors such as internal organization structures in large incumbents, so called business stealing effects, and individual and cognitive traits, to mention a few. ${ }^{1}$ Previous research

\footnotetext{
${ }^{1}$ For a survey, see Braunerhjelm (2011).
} 
relating labour mobility to innovation is considerably more limited and remains inconclusive (Agrawal et al. 2006). An early contribution was provided by Almeida and Kogut (1999), showing that interfirm mobility of engineers in Silicon Valley frequently were major patent holders and that they exerted a strong influence on firms' learning processes. More recently, these results have been corroborated by Oettl and Agrawal (2008), who claim that such knowledge flows accrue not only to the firm receiving employees but also to the firms that lose workers. The latter effect is due to increased knowledge flows and expanded social (knowledge) networks. Also, Kaiser et al. (2015) and Braunerhjelm et al. (2014) found a positive association between labour mobility and innovation, measured as patent applications. However, a negative relationship between innovation and mobility of highly qualified labour has also been established in previous literature (Balsvik 2011; Parrotta and Pozzoli 2012). ${ }^{2}$

Our prime interest in the current paper is to examine the influence of mobility of knowledge (R\&D) workers on innovation on firms distributed on separate size classes, small firms defined as those having less than 50 employees and medium-sized and large firms defined as those having more than 49 employees. ${ }^{3}$ The analysis will take into account both learning by hiring (firms receiving knowledge workers) and the diaspora effect (firms losing knowledge workers). To accomplish this, we will utilize a unique, matched Swedish dataset of employers and employees that features a number of characteristics at the individual, firm and regional levels (including patent applications) and allows us to track the movement of individuals among firms to investigate the ensuing effects on innovation. ${ }^{4}$ In our study, only patenting firms qualify as innovative, i.e. those firms that have filed at least one patent application. Nonpatenting firms are considered non-innovators.

We provide a number of new insights regarding the relationship between labour mobility, innovation and how it affects firms of different size. We believe that this is the first study to use extensive register data (a population) to investigate the size dimension when analyzing how labour mobility influence innovation (and

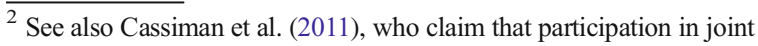
ventures is more conducive to innovation than labor mobility.

${ }^{3}$ This is in accordance with the EU's definition of small firms (less than 50 employees).

${ }^{4}$ Similar comprehensive data that are accessible for research can only, as far as we know, be found in Denmark, Finland and Norway.
}

one of the very few addressing this issue at all). Second, we control for other labour market categories, such as newly graduated knowledge workers and joiners of unknown origin. ${ }^{5}$ This extension is important since hiring researchers from universities have been shown to impact firms' patenting activities (Ejsing et al. 2013). Third, we have access to a considerably longer time series which comprise the entire business cycle, and a wider set of controls. ${ }^{6}$ We also present a separate analysis of the eight most innovative industries to see whether the results differ for high innovators. Fourth, we emphasize the geographical dimension of knowledge flows, i.e. how interregional versus intraregional mobility influences innovation output, an issue which has not been addressed in previous work but may entail important policy implications. Finally, the issues addressed are highly topical and policy-relevant against the background of faltering growth performance in large parts of the global economy and the call for structural reforms, not least within the European Union. As innovation is considered the engine of growth (Aghion and Howitt 2009), more thorough insights regarding the relationship between labour mobility and innovation are obviously a high-priority issue.

Our estimations support the proposition that the mobility of R\&D workers-whose definition builds on both educational and functional occupation data- has a positive impact on firms' innovation output. Interestingly enough, several distinctive differences emerge when we separate the estimations between small and large firms. More precisely, small firms are shown to be highly dependent on joiners from firms that previously have been engaged in innovation, whereas no such effect could be detected for larger firms. In addition, intraregional mobility is considerably more important for smaller firms, while larger firms benefit from both intraregional and interregional labour mobility. Smaller firms also benefit (weakly) from labour that has moved to other patenting firms. The opposite patterns prevail for larger firms. For a number of variables, the results were more pronounced for small firms belonging to the eight most innovative industries.

\footnotetext{
$\overline{5}$ Kaiser et al. (2011, p. 21) are aware about this potentially important data omission in their analysis and suggests that an interesting question for future research " $\ldots$ is how the mobility between university and private firms affects the knowledge production in these two sectors, as measured by patents and academic publications".

${ }^{6}$ The Danish study stretches over 2000-2004, while our analysis comprises the years 2001-2008.
} 
The rest of the paper is organized as follows. "Previous research" section reviews the previous research related to the issues addressed in this paper, which is followed by the theoretical framework and hypotheses development in "The Knowledge Spillover Theory of Intrapreneurship" section. Then, we present the empirical strategy in "Empirical methodology" section and description of the data in "Data" section. The regression results, separated into "firms learning by hiring" and "firms learning by diaspora", are shown in "Results" section. The paper ends with conclusions in "Conclusion" section.

\section{Previous research}

Acs and Audretsch $(1988,1990)$ were among the first to provide empirical evidence that despite modest $R \& D$ investments, small and entrepreneurial firms contribute substantially to innovation in the USA. Even though large corporations account for the overwhelming share of private R\&D outlays, innovative activities differ across industries and large firms did not account for the greatest amount of innovative activity in all industries. For example, Acs and Audretsch conclude that large firms were much more innovative in the aircraft and pharmaceutical industries, while the opposite prevailed in computers and process control instruments where small firms contributed the bulk of innovations. Also, Baldwin and Johnson (1999) attribute a particular important role to small firm innovations in certain industries (the electronics, instruments, medical equipment and biotechnology industries). Baldwin (1995) suggests that more successful firms adopt more innovative strategies. ${ }^{7}$

Thus, many entrepreneurs and small firms exploit existing knowledge - through their network and links to other knowledge producers - to satisfy their specific needs in the production of goods and services (Shane 2000; Freel 2003). Almeida and Kogut (1997) and Almeida (1999) show that small firms innovate in relatively unexplored fields of technology. Before that, Rothwell and Zegveld (1982) claimed that smaller firms more frequently introduced radical innovations. Baumol (2004) makes the same argument. Thereby, they also

\footnotetext{
${ }_{7}^{7}$ Large incumbents still play an essential role in economies, not least as creators of "market for ideas" (Gans and Stern 2003).
}

produce new knowledge, even if it does not show up in the R\&D statistics. ${ }^{8}$

These were the insights that formed the base for the KSTE. More precisely, the theory captures how entrepreneurs, taking advantage of their individual and heterogeneous skills and combining that with knowledge originating in $\mathrm{R} \& \mathrm{D}$ investments by incumbents, become the spillover vehicles required to convert knowledge into societal use. This theoretical foundation can also be used to explain intrapreneurship, i.e. why labour mobility may generate a more productive utilization of knowledge in incumbent firms. A better allocation of certain skills will enhance innovations, thereby promoting growth. We will return to these issues in the theoretical part.

Labour market flexibility can be defined in different ways, such as labour mobility within firms, between firms or in terms of wages. In this study, we are concerned with labour mobility between firms and its effects on innovation, as measured by patent applications. Theoretically, it can be demonstrated that labour mobility may either increase or decrease innovative performance. In the former case, labour mobility generates better matching and extended networks, which increases knowledge flows between firms (Hoisl 2007). The implicit assumption is that the effective allocation of knowledge embodied in labour requires mobility, i.e. it is preceded by a search process. On the other hand, a decrease in innovative performance may occur as a result of costlier administrative routines and/or harm to firm organizational learning and "internal memories" (Zhou et al. 2009).

It has been empirically demonstrated that mobility can increase productivity at the firm level (Nicoletti and Scarpetta 2003; Andersson and Thulin 2008). The proposed reasons are better matching between firm needs and the skills of labour (Bessen and Maskin 2009), spillovers of knowledge that is embodied in labour and extended externalities related to network effects (Pakes and Nitzan 1983; Mansfield 1985; Powell et al. 1996; Zucker et al. 1998; Song et al. 2003; Hoti et al. 2006). As new knowledge that is embodied in labour enters the firm, established processes and methods tend to be

\footnotetext{
${ }^{8}$ As Christensen (1997) has convincingly shown, large incumbents are not internally organized to adopt changes or produce innovations that may affect the usefulness or value of an existing production structure. Similarly, Aldrich and Auster (1990) make the simpler argument that the larger and older the firm, the less receptive to change the organization becomes. See Braunerhjelm (2011) for a survey.
} 
challenged. New knowledge provides new insights, increases efficiency and productivity and may lead to new business opportunities. New knowledge into the firm is also, in our view, an instrument to promote intrapreneurial innovative activities.

These findings regarding labour mobility and productivity can be expected to prevail also for innovation, not least since innovation is a means to augment productivity. More recently, there have also been a few attempts to specifically investigate how innovation performance is impacted by labour mobility. Utilizing Danish data, Kaiser et al. (2015) found that firms receiving knowledge workers from other firms, as well as those losing knowledge workers, improved their innovative performance as measured by patent applications. They conclude that the positive outcomes are related to extended and improved networks, accelerating the knowledge flows. ${ }^{9}$ However, the authors do not consider firm size or the regional origins of employees nor do they control for knowledge workers coming from the university, or how the market structure influence firm innovativeness.

Hoisl (2007) presents an analysis based on German data for the period 1993 to 1997 where individual data on inventors are combined with a selected number of aggregated industry variables. Her analysis shows a positive association between mobility and inventor productivity, indicating a better match between employers and employees and enhanced knowledge spillovers. ${ }^{10}$ But Hoisl also concludes that there is a simultaneous relationship where productive inventors become less mobile because they have found good matches. The results seem intuitively appealing; however, the representability of the respondents is not well accounted for and, as discussed by Hoisl (2007), may create problems with selection bias. Moreover, the analysis only considers the receiving firms and not those that the inventors have left.

As regards intraregional versus interregional mobility, the dominant predicament is that dense areas characterized by mobility are conducive to innovation and

\footnotetext{
${ }^{9}$ Kaiser et al. (2015) is one of the few studies that measures innovation using an output variable. See Song et al. (2003), Rosenkopf and Almeida (2003), Agrawal et al. (2006) and Corredoira and Rosenkopf (2010). At the same time, it should be stressed that measuring innovation is a difficult task, where patents and patent application are one but incomplete measure. See Hall (2011) for a review and discussion.

${ }^{10}$ For an early analysis of mobility and matching, see Topel and Ward (1992).
}

productivity. It is well established that knowledge flows are geographically localized (Jaffe et al. 1992; Audretsch and Feldman 1996; Almeida and Kogut 1999; Agrawal and Cockburn 2003; Thompson and Fox-Kean 2005). It has also been shown that firms are likely to patent more in regions that are characterized by high labour mobility (Kim and Marschke 2005; Thompson and Fox-Kean 2005). ${ }^{11}$ However, some scholars have suggested that intraregional movement is slightly less likely to yield new information for a firm and to propel innovation compared with interregional mobility due to the similarity of intraregional knowledge (Essletzbichler and Rigby 2005). The issue of whether interregional mobility is more instrumental in producing innovation than intraregional and whether firm size differences are important has to our knowledge not been subject to a rigorous empirical analysis.

Finally, there is also a literature on labour market regulations, firm size and innovativeness. Regulatory impediments to mobility may be of an informal or formal character (Breschi and Lissoni 2005, 2009). ${ }^{12}$ Even though firms are operating in the same national regulatory context in the current analysis, we claim that there may be divergent effects across firms of different size (Scarpetta and Tressel 2004; Zhou et al. 2011). ${ }^{13}$ Ichniowski and Shaw (1995) and Bassanini and Ernst (2002) conclude that primarily smaller firms' innovativeness tends to be negatively affected by labour market regulations.

In summary, theoretical models offer some guidance but are not at a consensus in their normative conclusions, whereas empirical research - although in varying degrees - seems to support a positive relationship between labour mobility and firm innovation. None of these have taken a comprehensive approach using register data to examine the effects on firms of different size or including the regional dimension.

\footnotetext{
$\overline{11}$ There is huge literature on clusters and agglomerations indicating that frequent job changes and close interactions between employees of different firms are a decisive factor in explaining success of such clusters (Saxenian 1994; Fallick et al. 2006).

${ }^{12}$ Firms may also seek to contractually restrain the mobility of employees defined as strategically important to guard against the loss of proprietary knowledge. These measures seem to have an ambiguous effect on firm innovation and fall outside the scope of the present analysis (Fosfuri and Rønde 2004; Franco and Mitchell 2008; Marx et al. 2009; Samila and Sorenson 2011).

${ }^{13}$ Zhou et al.'s (2011) analysis is based on survey data and defines small firms as those having less than 250 employees, while the smallest firms ( $<5$ employees) are excluded.
} 


\section{The knowledge spillover theory of intrapreneurship}

Knowledge is partly embodied in employees, which makes labour mobility relevant from a growth perspective. We argue that increased labour mobility is a way to enhance intrapreneurial activities through improved matching, higher allocation efficiency and extended network effects, thereby accelerating innovative activities. ${ }^{14}$ If this allegation is correct, it will be manifested in a positive relationship between labour mobility and innovation output.

According to the endogenous growth theory, $R \& D$ investments and knowledge spillovers can be expected to generate innovation, increased productivity and higher growth (Romer 1990; Aghion and Howitt 1998). Building on the endogenous growth theory, but emphasizing that the spillover mechanism was not well explained, Acs et al. (2009) presented a model where entrepreneurs were shown to constitute that missing link. Here, we argue that labour mobility of certain professions or skills is a complementary channel to diffuse knowledge and to spur innovation activities. We define intrapreneurs as individuals who are engaged in innovative activities within the firm.

Our theoretical framework builds on Vilalta-Bufí (2008) in which different types of intermediate goods are replaced with different types of human capital. Thus, we adopt a somewhat modified version of the VilaltaBufí (2008) model as our base for the Knowledge Spillover Theory of Intrapreneurship (KSTI). ${ }^{15}$

3.1 The knowledge spillover theory of intrapreneurship: a theoretical framework

The economy contains $N$ firms that are identical in all respects except for their firm-specific knowledge $(h)$, which is assumed to be embodied in each firm's workers. Firms can access knowledge (human capital) in three different ways. First, they can draw upon knowledge among their own experienced employees who remain in the firm (stayers). Second, they can acquire new knowledge by hiring experienced workers from other firms (joiners), and third, they can hire new

\footnotetext{
${ }^{14}$ Labour mobility may also positively affect entrepreneurship through similar mechanism, see Braunerhjelm et al. (2014).

${ }^{15}$ For details, see Vilalta-Bufi (2008). As in the original model, we exclude physical capital to make the model more tractable.
}

workers who have just entered the labour market (graduates). All of these channels have a potential of increasing intrapreneurial and innovative activities.

The introduction of new or modified products and services $(Y)$ can be modelled in the following way:

$Y_{i}=H_{i}^{\alpha} L_{i}^{1-\alpha}, \alpha \in(0,1)$

$H_{i}$ is a measure of human capital embodied in experienced workers, and $L_{i}$ represents the number of workers with no previous work experience; firms are identified by subindex $i$. Moreover, human capital is defined as a composite of the firm's own experienced workers and experienced workers hired from other firms that are involved in innovative activities,

$H_{i}=\left(\left(\lambda_{i}^{i} h_{i}\right)^{\alpha}+p \sum_{j \neq i}\left(\lambda_{i}^{j} h_{j}\right)^{\alpha}\right)^{\frac{1}{\alpha}}, p \in[0,1]$

In Eq. (2), $\lambda_{i}^{j}$ indicates the amount of joiners originating from firm $j$ that is used in production by firm $i$. Parameter $p$ measures how easily firms can access the external knowledge embodied in their new workers, which is determined in part by the institutional setting and the absorptive capacity of the hiring firm. Inserting the measure of human capital into the production function and assuming that all firms employ the same number of new workers with no experience (here set equal to one for simplicity), production can be written as

$Y_{i}=\left(\lambda_{i}^{i} h_{i}\right)^{\alpha}+p \sum_{j \neq i}\left(\lambda_{i}^{j} h_{j}\right)^{\alpha}$

It is costly for a worker to move to a new firm; therefore, firms must pay a wage premium $m$ to attract workers from other firms. Firms choose the number of workers to retain and the number of experienced workers to hire from other firms to maximize their profits. Using the first-order conditions from the profit maximizing problem and imposing market-clearing yields the following equilibrium condition:

$\alpha\left(1-(N-1) \lambda^{i^{*}}\right)^{\alpha-1} h_{i}^{\alpha}=p \alpha\left(\lambda^{i^{*}}\right)^{\alpha-1} h_{i}^{\alpha}-m$

where $\lambda^{i *}$ is the optimal amount of labour to poach by each firm. The solution is interior, which ensures positive labour mobility in equilibrium. Hence, according to the model, firms hire workers from other firms in 
equilibrium to enhance their knowledge base. Presumably, this higher knowledge base should also affect firms' intrapreneurship capacity and establish a causal link between labour mobility and innovation.

Building on Vilalta-Bufí (2008), Rosenkopf and Almeida (2003) and Song et al. (2003), we refer to the knowledge-enhancing effect that occurs through recruiting new employees as the firm "learning-by-hiring" effect. Over time, as new worker knowledge is diffused into the new firm, and as their network with former colleagues from the sourcing firm diminishes, the effect gradually tails off. We can extend the model by assuming that workers who left a firm continue to be included in the knowledge creation process by transferring knowledge from their new employers to their old employers. The mechanism is the same as for the receiving firm because workers frequently maintain their social relationships after leaving the firm (Crane 1969; Oettl and Agrawal 2008) and should also peter out over time. We refer to this process as the firm "learning-by-diaspora" effect.

Thus far, we have considered knowledge upgrading through employees without considering the geographical dimension. To include the effect of geographical distance, we classify labour mobility into two different types: intraregional and interregional labour mobility, based on whether the sourcing and receiving firms are located in the same region. Firms' knowledge upgrading thus involves four types of human capital: joiners, leavers, stayers and graduates. Furthermore, joiners and leavers can be divided into two subgroups depending on whether they move across regional borders.

\subsection{Hypotheses}

Our hypotheses are based on the theoretical framework outlined above and on the literature review, bearing in mind that previous theoretical and empirical contributions are both scarce and ambiguous. However, there are compelling indications that labour mobility leads to increased knowledge diffusion and knowledge exchange (within and between firms) and positively influences labour productivity. For similar reasons, we expect that mobility of knowledge workers should contribute to enhanced intrapreneurship abilities and be positively associated with firm innovation activities, particularly for certain skill cohorts and when those joining a firm come from a patenting firm. Also, leavers may contribute to knowledge and a firm's innovative capacity, but we expect this influence to be of a lower range. In addition, we argue that a more fluid labour market will primarily benefit smaller firms due to fixed costs in hiring and scouting for relevant knowledge workers. Moreover, building on the results indicating that proximity is likely to generate more knowledge flows, we hypothesize that intraregional labour mobility is likely to have a stronger effect on firm innovation capability than interregional labour mobility. Nonetheless, there are results pointing in the opposite direction, i.e. that an inflow of knowledge from more remote environments generates more innovation. Finally, we argue that it is important to control for market structure in the empirical analysis.

\section{Empirical methodology}

\subsection{R\&D workers and labour mobility}

The theoretical model highlights the general role that labour mobility plays in promoting intrapreneurship and knowledge transfers across firms. It is likely, however, that this effect is particularly strong for more educated workers and workers engaged in R\&D. Empirical support for this claim can be found in Ejermo and Jung (2014), who show that Swedish inventors tend to be better educated than the average worker and that their level of education has increased over the years. The percentage of inventors who had a minimum of 2 years of higher education was $44 \%$ in 1985 and had increased to $76 \%$ by 2007. Among these, $14 \%$ held a $\mathrm{PhD}$ degree in 1985 , whereas the corresponding share was $29 \%$ in 2007.

In addition to formal education, the type of job that a worker has is likely to influence the extent of knowledge transfers between firms that follows from labour mobility. Consequently, this study focuses on the labour mobility of highly educated workers who are more or less directly involved in producing new knowledge within firms. More precisely, the worker should hold at least a bachelor's degree in natural, technical, agriculture or health science and be classified as "professionals" according to the Swedish Standard Classification of Occupations (SSYK=2). ${ }^{16}$ We name this group of workers "R\&D workers". In addition, we denote those with the same level of education but belonging to the group "technicians and associate professionals" (SSYK = 3)

\footnotetext{
${ }^{16}$ The Swedish Standard Classification of Occupations SSYK is based on the International Standard Classification of Occupations (ISCO-88).
} 
as “associate R\&D workers". Together, R\&D workers and associate R\&D workers make up the firms' R\&D workforce, i.e. the major share of their intrapreneurs. ${ }^{17}$

$R \& D$ workers are further divided into one of the following seven groups, depending on their labour market status ${ }^{18}$ :

- Joiners from patenting firms (JP). R\&D workers who arrived from a patenting firm between year $t-1$ and $t$.

- Joiners from non-patenting firms (JNP). R\&D workers who arrived from a non-patenting firm between year $t-1$ and $t$.

- Leavers to patenting firms (LP). R\&D workers who left the firm at year $t-1$ and work as a professional at a patenting firm in year $t$.

- Leavers to non-patenting firms (LNP). R\&D workers who left the firm at time $t-1$ and work as a professional at a non-patenting firm in year $t$.

- Graduates from tertiary education $(G)$. R\&D workers arriving from tertiary education between year $t-1$ and $t$.

- Other joiners $(\mathrm{O})$. $\mathrm{R} \& \mathrm{D}$ workers joining a firm for whom we have no information on their previous job position.

- Stayers (S). R\&D workers who are employed by the same firm in year $t-1$ and $t$.

Finally, we also classify job switchers as either intraregional or interregional - depending on whether the receiving firm and the sourcing firm are located in the same region - to test whether distance has an effect on firm patenting activities.

\subsection{Econometric specification}

We depart from a firm-level knowledge production function in which physical capital $(K)$ and human capital $(H)$ are combined to produce new knowledge $(P)$ according to

$P=A K^{\alpha} H^{\beta}, \alpha, \beta>0$

\footnotetext{
${ }^{17}$ Henceforth, we assume that R\&D workers are synonymous with intrapreneurs.

${ }^{18}$ The notation in parentheses is subsequently used to identify the different types of workers in the empirical analysis.
}

Following Griliches (1967), we specify our qualityadjusted labour input $H$ as an additive composite of different types of workers. In particular, we define human capital as a weighted aggregate of the different types of workers who currently are employed by the firm and as employees who recently left the firm,

$$
\begin{aligned}
H= & \gamma_{J P} L_{J P}+\gamma_{J N P} L_{J N P}+\gamma_{L P} L_{L P}+\gamma_{L N P} L_{L N P} \\
& +\gamma_{G} L_{G}+\gamma_{O} L_{O}+L_{S}+\gamma_{A W} L_{A W}
\end{aligned}
$$

where subscript AW denotes associate $\mathrm{R} \& \mathrm{D}$ workers (the other subscripts are defined above). $L_{x}$ denotes the amount of each specific type of labour $x$ used by the firm, and the $\gamma$-coefficients denote each type of worker's marginal contribution to the composite measure of human capital where we have normalized marginal productivity for stayers to one. ${ }^{19}$ This enables us to express the knowledge production function as

$$
\begin{aligned}
P= & \exp \left[\ln A+\alpha \ln K+\beta \ln L+\beta_{J P} S_{J P}+\beta_{J N P} S_{J N P}+\right. \\
& \left.+\beta_{L P} s_{L P}+\beta_{L N P} s_{L N P}+\beta_{G} s_{G}+\beta_{O} s_{O}+\beta_{A W} s_{A W}\right]
\end{aligned}
$$

where $s$ stands for the number of workers within each category divided by the firm's overall R\&D workforce (i.e. the sum of $R \& D$ workers and associate $R \& D$ workers), $L$. The derived knowledge production function constitutes the base for our econometric analysis, and it is estimated using the following regression equation:

$$
\begin{gathered}
P_{i, t}=\exp \left[\ln A+\alpha \ln K_{i, t}+\beta \ln L_{i, t}+\beta_{J P} S_{J P, i, t}+\beta_{J N P} S_{J N P, i, t}+\right. \\
+\beta_{L P} s_{L P, i, t}+\beta_{L N P} s_{L N P, i, t}+\beta_{G} s_{G, i, t}+\beta_{O} S_{O, i, t} \\
\left.+\beta_{A W} S_{A W, i, t}+\mathbf{X}_{i, t}^{\prime} \boldsymbol{\delta}\right]
\end{gathered}
$$

where subscripts $i$ and $t$ denote firm and time, respectively. Vector $\mathbf{X}$ contains the variables we must control for that might otherwise distort the relationship between labour mobility and innovation.

Equation (8) will be estimated separately for firms with less than 50 employees and for firms with 50 or more employees to allow the effect of the explanatory variables, and in particular the labour mobility variables, to differ between small and larger firms. The relationship between labour mobility and innovation will be estimated using the negative binomial estimator, which is an appropriate

\footnotetext{
${ }^{19}$ Note that normalizing marginal productivity for stayers to one means that we must interpret the effect of the other types of labour as relative to stayers.
} 
estimator given our setting where the dependent variable is count data and the mean number of patents is considerably lower than its standard deviation. Hence, our dependent variable exhibits clear signs of over dispersion, which renders the otherwise appropriate Poisson estimator inadequate. The remaining parts of this section present the control variables contained in vector $\mathbf{X}$.

\subsection{Firm-specific heterogeneity}

According to Blundell et al. (1995), firm-specific heterogeneity in innovative capacity can be controlled for if we include a dummy variable equal to one if the firm had ever innovated during a pre-sample period and zero otherwise, along with the mean number of innovations during the pre-sample period. ${ }^{20}$ Here, we choose $1987-$ 2000 as our pre-sample period to estimate firm heterogeneity, but we also follow Kaiser et al. (2015) and extend the pre-sample estimator as suggested by Blundell et al. (1995) to account for the proportion of patent applications in a given year, ${ }^{21}$

$\ln F E_{i, t}=\ln \left[\frac{\sum_{t=1}^{T} P_{i, t} / P_{t}}{T}\right]$

$P_{i, t}$ denotes the number of patent applications for firm $i$ in year $t$ and $P_{t}$ the total number of patent applications for all firms in year $t$. $T$ represents the total number of years during the pre-sample period (1987-2000). Therefore, if firm $i$ innovates during a year in which few other firms innovate, it will carry a higher weight in the average innovative capacity of the firm.

\subsection{Firm-specific capital stocks}

Due to a lack of data, we use the perpetual inventory method to reconstruct the physical capital stocks from investments according to,

$K_{i, t+1}=(1-\theta) K_{i, t}+I_{i, t+1}$

where $K_{i, t}$ denotes firm $i$ 's physical capital stock at time $t, \theta$ represents the depreciation rate (assumed to be equal

\footnotetext{
$\overline{{ }^{20}}$ This will also account for the so-called zero inflation problem that arises in settings with an excess number of zeros.

${ }^{21}$ We have also run regressions using the original pre-sample estimator by Blundell et al. (1995), and the results are basically unaltered.
}

to 0.05 for all firms) and $I$ represents investments deflated by the GDP deflator. We choose the pre-sample period $1987-2000$ to create the initial capital stocks used in the estimation period beginning in 2001.

\subsection{Regional control variables}

We include seven regional control variables in the regressions. First, we control for the general level of labour mobility within and across regions by including three variables. The first variable-labour inflow to the region - is defined as the total number of employees in the region who worked in a firm located in another region the previous year, divided by the total number of workers in the region. The second variable-labour outflow from the region-is defined as the total number of workers who left the region to take a new job in another region, divided by the total numbers of workers in the region. The third and final variable controls for the general level of labour mobility within regions and is defined as the total number of workers in the region who had switched employers within the region divided by the total number of workers in the same region.

We further control for employment density (number of employed per square kilometre), human capital intensity (share of employed with a tertiary education) and industry diversity (Herfindahl index based on regional employment in three-digit industries) in the regions.

We also include an accessibility variable that is based on the surrounding regions' patent applications to control for potential spatial autocorrelation (see Andersson et al. 2007). Failure to control for this effect in the regression analysis might introduce bias in our estimator. Finally, we include dummy variables for industries, years and regions.

\section{Data}

We extracted the personal and firm-level data from Statistics Sweden's Business Register from 1987 to 2008, where the estimation period is 2001-2008 and the pre-sample period is $1987-2000 .^{22}$ This unique database covers all firms and individuals in

\footnotetext{
22 Much data is available also for the 2008-2013 period. The empirical analysis is, however, limited to the period 2001-2008 for the simple reason that several definitions and industry classifications were changed in Statistics Sweden's database on occupations, the Swedish Standard Classification of Occupations (SSYK), in 2009 and the following years.
} 
Sweden, and firms are linked to one another through their hiring activities in the labour market. The matched employer-employee dataset can thus be used to trace how networks are generated through labour mobility. In addition, the data contain individual information regarding educational background, job classification (functions), etc., which enables labour to be distinguished into different types of human capital. Innovation output can then be regressed on these classes of human capital at the firm level. ${ }^{23}$

The dataset contains 1,127,832 firms and 1,206,182 establishments; among these, $97.5 \%$ of the firms are privately owned. The majority of firms are operated as sole proprietorships $(53.7 \%)$ and limited liability companies (33.1\%). ${ }^{24}$ Patent application data cover the 1987-2008 period, and 8607 firms owned 154,763 patent applications in 2008. In the sample, all firms founded during the estimated time period (2001-2008) are excluded because we need the firm pre-sample innovation activities to distinguish the innovators. Firms from the public sector are also excluded because the differences in patenting activities between the public sector and the private sector are likely to be substantial. The objectives of public firms differ radically from private firms; for example, R\&D expenditure is more focused on basic research, whereas the private sector tends to pay more attention to applied research and experimental research. ${ }^{25}$ Furthermore, we only include firms with at least one R\&D relevant worker, ${ }^{26}$ which is used to separate firms that have the intention to innovate from other firms.

Those who switch jobs between firms are also distinguished by the firm innovation status, i.e. whether they are working in patenting or nonpatenting firms. Moreover, we distinguish between

\footnotetext{
$\overline{23}$ The data that support the findings of this study are available from Statistics Sweden, but restrictions apply to the availability of these data, which were used under license for the current study, and so are not publicly available. Data are however available from the authors upon reasonable request and with permission of Statistics Sweden.

${ }^{24}$ Regarding different types of ownership, there are 1076 state-owned, 2271 municipal-owned, 168 region-owned, 1,009,810 private, nonconsolidated-owned, 90,412 private group-owned and 24,095 foreign-owned firms.

${ }^{25}$ The data can be found at the OECD website, science, technology and patents (http://stats.oecd.org).

${ }^{26} \mathrm{R} \& \mathrm{D}$ relevant workers comprise $\mathrm{R} \& \mathrm{D}$ workers and associate $\mathrm{R} \& \mathrm{D}$ workers.
}

intraregional and interregional labour mobility. ${ }^{27}$ Pooling the individual-level and firm-level data leaves us with a final sample of 91,668 observations with 21,662 unique firms and 32,742 patent applications between 2001 and 2008. The sample is dominated by firms with fewer than 50 employees, which together account for approximately $79 \%$ of the observations.

We use patent applications as a measurement of knowledge output, which is the most commonly used indicator of new knowledge creation (Griliches 1990; Alcacer and Gittelman 2006). Despite the limitation of using patent applications (invention does not always lead to innovation), it is nevertheless a better indicator of firm knowledge creation compared with granted patents and patent citations, which are subject to substantial time lag delays.

\section{Results}

\subsection{Descriptive statistics}

Descriptive statistics of the data sample and detailed variable descriptions are presented in Tables 7, 8, 9, 10, 11, 12 and 13 in the Appendix, in which firms are divided into subgroups based on their pre-sample period innovation status and firm size. This allows us to see the trend of labour mobility between innovators and noninnovators as well as differences across small and large firms. $^{28}$

On average, each firm has 79.8 employees, 7.2 $\mathrm{R} \& \mathrm{D}$ relevant workers and a real capital stock amounting to 67.2 million Swedish Krona. Separating patenting from non-patenting firms during the pre-sample period shows that patenting firms are larger with bigger capital stocks (326.4 employees, 33.1 R\&D relevant workers and a real capital stock of 304.4 million Swedish Krona) compared with non-patenting firms (54.6 employees, 4.6 R\&D relevant workers and a real capital stock of 43 million

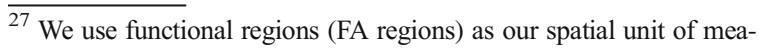
surement. These regions have been defined by the Swedish Agency for Economic and Regional Growth (Tillväxtverket) as geographical areas in which people can live and work without lengthy commutes. They thus comprise local labor markets and are delineated based on commuting intensities. According to this definition, there are 72 FA regions in Sweden.

${ }^{28}$ A full correlation matrix is available from the authors upon request.
} 
Swedish Krona). The average number of patent applications among all firms during the estimation period 2001-2008 is 0.36 , whereas the number of applications for firms that had at least one patent application during the 1987-2000 pre-sample period is much higher (3.7 applications). To sum up, innovative firms are larger, have bigger capital stocks and more human capital and are also more likely to be innovative in the future compared with noninnovative firms. The same pattern also holds when we divide the sample into small and larger firms as shown in Tables 10, 11, 12 and 13.

Regarding R\&D worker mobility, firms with presample patents seem more connected with other patenting firms, as shown by their relatively higher shares of joiners from patenting firms and leavers to other patenting firms. Moreover, firms that applied for a patent during the pre-sample period have on average a lower share of stayers in the firm compared with other firms.

Table 1 Results from negative binomial regressions: small firms (0-49 employees)
$* * *, * *$ and $*$ denote statistical significance at the 1,5 and 10 percentage level, respectively. $t$ statistics based on robust standard errors in parentheses
6.2 Learning by hiring and diaspora effects — small versus larger firms

The results from the negative binomial regressions are shown in Tables 1 and 2, where the former refers to firms smaller than 50 employees. The cut-off number of 50 employees has been chosen so as to correspond to OECD's classification of small firms, i.e. 0-49 employees. Starting with small firms in Table 1, the first column distinguishes between joiners and leavers, while column 2 also considers the sourcing and receiving firms' innovative status. The specification in column 3 adds the spatial dimension to the analysis, where we distinguish between intraregional and interregional mobility of workers, and finally, regional control variables as well as more detailed industry dummies are added in column 4.

Non-mobile R\&D workers (stayers) constitute the base category of $R \& D$ workers in the analysis, and hence, the results must be interpreted as relative to

\begin{tabular}{|c|c|c|c|c|}
\hline & (1) & (2) & (3) & (4) \\
\hline \multicolumn{5}{|l|}{$\mathrm{R} \& \mathrm{D}$ workers } \\
\hline Joiners ... & $\begin{array}{l}0.485 * * * \\
(2.79)\end{array}$ & & & \\
\hline$\ldots$ from patenting firms & & $\begin{array}{l}0.973 * * * \\
(4.68)\end{array}$ & & \\
\hline$\ldots$ intraregional & & & $\begin{array}{l}1.116 * * * \\
(4.74)\end{array}$ & $\begin{array}{l}1.093 * * * \\
(4.49)\end{array}$ \\
\hline$\ldots$ interregional & & & $\begin{array}{l}0.639^{*} \\
(1.70)\end{array}$ & $\begin{array}{l}0.714 * \\
(1.96)\end{array}$ \\
\hline ... from non-patenting firms & & $\begin{array}{l}0.186 \\
(0.69)\end{array}$ & & \\
\hline ... intraregional & & & $\begin{array}{l}0.330 \\
(1.06)\end{array}$ & $\begin{array}{l}0.385 \\
(1.56)\end{array}$ \\
\hline ... interregional & & & $\begin{array}{l}-0.267 \\
(-0.69)\end{array}$ & $\begin{array}{l}-0.208 \\
(-0.57)\end{array}$ \\
\hline Leavers ... & $\begin{array}{l}0.122 \\
(0.69)\end{array}$ & & & \\
\hline$\ldots$ to patenting firms & & $\begin{array}{l}0.628 \\
(1.29)\end{array}$ & & \\
\hline$\ldots$ intraregional & & & $\begin{array}{l}0.578 \\
(0.91)\end{array}$ & $\begin{array}{l}0.480 \\
(1.13)\end{array}$ \\
\hline$\ldots$ interregional & & & $\begin{array}{l}0.793 \\
(1.18)\end{array}$ & $\begin{array}{l}0.593 \\
(0.87)\end{array}$ \\
\hline ... to non-patenting firms & & $\begin{array}{l}-0.253 \\
(-0.79)\end{array}$ & & \\
\hline
\end{tabular}


Table 1 (continued)

\begin{tabular}{|c|c|c|c|c|}
\hline & (1) & (2) & (3) & (4) \\
\hline \multirow[t]{2}{*}{$\ldots$ intraregional } & & & -0.494 & -0.471 \\
\hline & & & $(-1.06)$ & $(-1.07)$ \\
\hline \multirow[t]{2}{*}{$\ldots$ interregional } & & & 0.128 & 0.155 \\
\hline & & & $(0.30)$ & $(0.39)$ \\
\hline \multirow[t]{2}{*}{ Other joiners } & 0.373 & 0.379 & 0.375 & 0.372 \\
\hline & $(0.98)$ & $(1.00)$ & $(0.98)$ & $(0.93)$ \\
\hline \multirow[t]{2}{*}{ Graduates } & 0.277 & 0.271 & 0.285 & 0.185 \\
\hline & $(0.24)$ & $(0.23)$ & $(0.25)$ & $(0.15)$ \\
\hline \multirow{2}{*}{$\begin{array}{l}\text { Interaction variable between } \\
\text { graduates and a dummy for } \\
\text { firms with pre-sample patents }\end{array}$} & -1.116 & -0.957 & -1.006 & -1.205 \\
\hline & $(-0.76)$ & $(-0.65)$ & $(-0.69)$ & $(-0.81)$ \\
\hline \multirow[t]{2}{*}{ Associate $\mathrm{R} \& \mathrm{D}$ workers } & -0.113 & -0.112 & -0.118 & -0.115 \\
\hline & $(-0.95)$ & $(-0.95)$ & $(-1.00)$ & $(-0.98)$ \\
\hline \multirow[t]{2}{*}{ Total R\&D work force, logarithm } & $0.272 * * *$ & $0.273 * * *$ & $0.277 * * *$ & $0.262 * * *$ \\
\hline & $(4.60)$ & $(4.62)$ & $(4.69)$ & $(4.39)$ \\
\hline \multirow[t]{2}{*}{ Capital stock, logarithm } & 0.0502 & 0.0498 & 0.0490 & 0.0373 \\
\hline & $(1.59)$ & $(1.57)$ & $(1.57)$ & $(1.33)$ \\
\hline \multirow[t]{2}{*}{$\mathrm{FE}$, logarithm } & $0.291 * * *$ & $0.288 * * *$ & $0.289 * * *$ & $0.289 * * *$ \\
\hline & $(6.70)$ & $(6.67)$ & $(6.70)$ & $(6.92)$ \\
\hline \multirow[t]{2}{*}{ FE, dummy } & $3.122 * * *$ & $3.099 * * *$ & $3.102 * * *$ & $2.996 * * *$ \\
\hline & $(17.31)$ & $(17.24)$ & $(17.24)$ & (16.88) \\
\hline \multirow[t]{2}{*}{ Dummy patent $t-1$} & $2.791 * * *$ & $2.786 * * *$ & $2.778 * * *$ & $2.634 * * *$ \\
\hline & $(23.90)$ & $(23.75)$ & $(23.79)$ & $(24.09)$ \\
\hline \multirow[t]{2}{*}{ Dummy patent $t-2$} & $0.894 * * *$ & $0.884 * * *$ & $0.884 * * *$ & $0.781 * * *$ \\
\hline & $(7.25)$ & $(7.17)$ & $(7.19)$ & $(6.91)$ \\
\hline \multirow[t]{2}{*}{ Labour mobility into the region } & & & & 29.50 \\
\hline & & & & $(1.23)$ \\
\hline \multirow{2}{*}{$\begin{array}{l}\text { Labour mobility out from the } \\
\text { region }\end{array}$} & & & & 0.591 \\
\hline & & & & $(0.11)$ \\
\hline \multirow[t]{2}{*}{ Intraregional labour mobility } & & & & -2.486 \\
\hline & & & & $(-0.55)$ \\
\hline \multirow[t]{2}{*}{ Tertiary education rate } & & & & -2.800 \\
\hline & & & & $(-0.84)$ \\
\hline \multirow[t]{2}{*}{ Regional density } & & & & $-0.107 *$ \\
\hline & & & & $(-1.80)$ \\
\hline \multirow[t]{2}{*}{ Accessibility } & & & & $0.246^{*}$ \\
\hline & & & & $(1.90)$ \\
\hline \multirow[t]{2}{*}{ Specialization } & & & & -8.784 \\
\hline & & & & $(-0.54)$ \\
\hline \multirow[t]{2}{*}{ Industry dummies } & 1-digit & 1-digit & 1-digit & 3-digit \\
\hline & NACE & NACE & NACE & NACE \\
\hline Year dummies & Yes & Yes & Yes & Yes \\
\hline Regional dummies & Yes & Yes & Yes & Yes \\
\hline Number of observations & 72,431 & 72,431 & 72,431 & 72,431 \\
\hline
\end{tabular}


Table 2 Results from negative binomial regressions: larger firms (50+ employees)
$* * *, * *$ and $*$ denote statistical significance at the 1, 5 and 10 percentage level, respectively. $t$ statistics based on robust standard errors in parentheses
(1)

(2)

(3)

(4)

R\&D workers

Joiners ...

$0.588 * *$

(2.34)

... from patenting firms

0.248

(0.70)

... intraregional

0.535

0.233

(1.26)

(0.58)

... interregional

0.519

0.0544

(0.81)

(0.09)

... from non-patenting firms

$0.738 * * *$

(2.63)

... intraregional

... interregional

$\begin{array}{ll}0.957 * * * & 0.778 * * \\ (2.80) & (2.34) \\ 1.198 * * * & 1.058 * * \\ (2.86) & (2.34)\end{array}$

Leavers ...

$-0.460 * *$

$(-1.99)$

$-0.201$

$(-0.49)$

... intraregional

... interregional

... to non-patenting firms

$-0.562 *$

$(-1.90)$

... intraregional

... interregional

$\begin{array}{ll}0.310 & 0.0354 \\ (0.66) & (0.07) \\ -0.637 & -1.042 \\ (-0.75) & (-1.58)\end{array}$

$-0.111$

0.0439

$(-0.30)$

(0.14)

$-1.187 * * *$

$-1.224 * * *$

$(-2.74)$

$(-2.67)$

Other joiners

$-0.786 *$

$-0.759 *$

$-0.453$

$-0.240$

$(-1.75)$

$(-1.71)$

$(-1.00)$

$(-0.55)$

Graduates

$-0.230$

$-0.144$

0.210

$-0.647$

$(-0.19)$

$(-0.12)$

(0.18)

$(-0.39)$

Interaction variable between

0.939

0.876

0.218

1.206

graduates and a dummy for

firms with pre-sample patents

(0.55)

(0.53)

(0.13)

(0.59)

Associate R\&D workers

$-0.240 * *$

$-0.225 * *$

$-0.00187$

$-0.111$

$(-2.24)$

$(-2.11)$

$(-0.02)$

$(-1.01)$

Total R\&D work force,

$0.157 * * *$

$0.161 * * *$

$0.226 * * *$

$0.281 * * *$

logarithm

Capital stock, logarithm

(6.52)

(6.72)

(9.24)

(9.95)

$-0.0107$

$-0.0119$

$0.0457 * * *$

$0.0659 * * *$

$(-1.05)$

$(-1.18)$

(3.19)

(4.48)

FE, logarithm

$0.593 * * *$

$0.414 * * *$

$0.350 * * *$

(22.36)

(22.45)

(17.38)

(14.86) 
Table 2 (continued)

\begin{tabular}{|c|c|c|c|c|}
\hline & (1) & (2) & (3) & (4) \\
\hline FE, dummy & $\begin{array}{l}2.878 * * * \\
(24.87)\end{array}$ & $\begin{array}{l}2.897 * * * \\
(25.25)\end{array}$ & $\begin{array}{l}2.528 * * * \\
(22.07)\end{array}$ & $\begin{array}{l}2.270 * * * \\
(19.64)\end{array}$ \\
\hline Dummy patent $t-1$ & $\begin{array}{l}2.556 * * * \\
(26.69)\end{array}$ & $\begin{array}{l}2.558 * * * \\
(27.00)\end{array}$ & $\begin{array}{l}2.581 * * * \\
(28.82)\end{array}$ & $\begin{array}{l}2.362 * * * \\
(28.26)\end{array}$ \\
\hline Dummy patent $t-2$ & $\begin{array}{l}0.783 * * * \\
(8.47)\end{array}$ & $\begin{array}{l}0.782 * * * \\
(8.51)\end{array}$ & $\begin{array}{l}0.914 * * * \\
(10.64)\end{array}$ & $\begin{array}{l}0.831 * * * \\
(10.44)\end{array}$ \\
\hline Labour mobility into the region & & & & $\begin{array}{l}-3.240 \\
(-0.20)\end{array}$ \\
\hline $\begin{array}{l}\text { Labour mobility out from the } \\
\text { region }\end{array}$ & & & & $\begin{array}{l}1.050 \\
(0.80)\end{array}$ \\
\hline Intraregional labour mobility & & & & $\begin{array}{l}-0.786 \\
(-0.30)\end{array}$ \\
\hline Tertiary education rate & & & & $\begin{array}{l}-2.350 \\
(-0.99)\end{array}$ \\
\hline Regional density & & & & $\begin{array}{l}-0.0241 \\
(-0.75)\end{array}$ \\
\hline Accessibility & & & & $\begin{array}{l}0.183^{*} \\
(1.92)\end{array}$ \\
\hline Specialization & & & & $\begin{array}{l}12.08 \\
(0.91)\end{array}$ \\
\hline Industry dummies & $\begin{array}{l}\text { 1-digit } \\
\text { NACE }\end{array}$ & $\begin{array}{l}\text { 1-digit } \\
\text { NACE }\end{array}$ & $\begin{array}{l}\text { 1-digit } \\
\text { NACE }\end{array}$ & $\begin{array}{l}\text { 3-digit } \\
\text { NACE }\end{array}$ \\
\hline Year dummies & YES & YES & YES & YES \\
\hline Regional dummies & YES & YES & YES & YES \\
\hline Number of observations & 19,237 & 19,237 & 19,237 & 19,237 \\
\hline
\end{tabular}

Table 3 Estimated relative patent productivities: small firms (0-49 employees)
$* * *, * *$ and $*$ denote statistical significance at the 1,5 and 10 percentage level, respectively
(1)

(2)

(3)

(4)
$2.783 * * *$

$4.564 * * *$

$\begin{array}{ll}5.029 * * * & 5.172 * * * \\ 3.307 * & 3.725 *\end{array}$

1.681

$\begin{array}{cc}2.191 & 2.469 \\ 0.036 & 0.206\end{array}$

1.449

3.300

$\begin{array}{ll}3.087 & 2.832 \\ 3.863 & 3.263\end{array}$

0.073

$\begin{array}{ll}-0.783 & -0.798 \\ 1.462 & 1.592\end{array}$


Table 3 (continued)

(1)

\begin{tabular}{|c|c|c|c|c|}
\hline Other joiners & 2.371 & 2.388 & 2.354 & 2.420 \\
\hline \multicolumn{5}{|l|}{ Graduates ... } \\
\hline $\begin{array}{l}\ldots \text { for firms with } \\
\text { pre-sample patents }\end{array}$ & -2.085 & -1.513 & -1.603 & -2.893 \\
\hline $\begin{array}{l}\ldots \text { for firms without } \\
\text { pre-sample patents }\end{array}$ & 2.018 & 1.993 & 2.029 & 1.706 \\
\hline Associate R\&D workers & $0.585 * * *$ & $0.590 * * *$ & $0.574 * * *$ & $0.561 * * *$ \\
\hline Industry dummies & $\begin{array}{l}\text { 1-digit } \\
\text { NACE }\end{array}$ & $\begin{array}{l}\text { 1-digit } \\
\text { NACE }\end{array}$ & $\begin{array}{l}\text { 1-digit } \\
\text { NACE }\end{array}$ & $\begin{array}{l}\text { 3-digit } \\
\text { NACE }\end{array}$ \\
\hline Regional control variables & No & No & No & Yes \\
\hline
\end{tabular}

stayers. According to the regression results for firms having less than 50 employees, the firm learning by hiring effect (joiners) is basically supported. Joiners contribute positively and significantly to innovation (the number of patent applications) in the firms to which they have moved. Interestingly enough, the effect is confined to $R \& D$ labour originating from patenting firms (column 2), whereas no such effect could be detected from those arriving from non-patenting firms. The learning by diaspora effect is not supported by our results as shown by the insignificant effect of leavers.

Finally, when we examine other categories of the labour force, both graduates and other joiners fail to achieve statistical significance at any reasonable level.
Table 4 Estimated relative patent productivities: larger firms $(50+$ employees)
$* * *, * *$ and $*$ denote statistical significance at the 1,5 and 10 percentage level, respectively
(1)
(2)
(3)
(4)

\begin{tabular}{|c|c|c|c|c|}
\hline \multicolumn{5}{|l|}{ R\&D workers } \\
\hline Joiners ... & $4.745 * *$ & & & \\
\hline$\ldots$ from patenting firms & & 2.540 & & \\
\hline ... intraregional & & & 3.367 & 1.829 \\
\hline ... interregional & & & 3.296 & 1.194 \\
\hline ... from non-patenting firms & & $5.584 * * *$ & & \\
\hline ... intraregional & & & $5.235 * * *$ & $3.769 * *$ \\
\hline ... interregional & & & $6.301 * * *$ & $4.765 * *$ \\
\hline Leavers ... & $-1.930 * *$ & & & \\
\hline ... to patenting firms & & -0.248 & & \\
\hline$\ldots$ intraregional & & & 2.372 & 1.126 \\
\hline ... interregional & & & -1.819 & -2.708 \\
\hline ... to non-patenting firms & & $-2.491^{*}$ & & \\
\hline ... intraregional & & & 0.509 & 1.156 \\
\hline ... interregional & & & $-4.252 * * *$ & $-3.356 * * *$ \\
\hline Other joiners & $-4.006^{*}$ & $-3.714^{*}$ & -1.004 & 0.146 \\
\hline \multicolumn{5}{|l|}{ Graduates ... } \\
\hline $\begin{array}{l}\ldots \text { for firms with } \\
\text { pre-sample patents }\end{array}$ & 5.516 & 5.547 & 2.894 & 2.989 \\
\hline $\begin{array}{l}\ldots \text { for firms without } \\
\text { pre-sample patents }\end{array}$ & -0.465 & 0.106 & 1.929 & -1.302 \\
\hline Associate $\mathrm{R} \& \mathrm{D}$ workers & $-0.529 * *$ & $-0.398 * *$ & 0.992 & 0.605 \\
\hline Industry dummies & 1-digit NACE & 1-digit NACE & 1-digit NACE & 3-digit NACE \\
\hline Regional control variables & No & No & No & Yes \\
\hline
\end{tabular}


Table 5 Estimated relative patent productivities, manufacturing and eight innovative industries: small firms (0-49 employees)
$* * *, * *$ and $*$ denote statistical significance at the 1,5 and 10 percentage level, respectively. The group of eight industries is identified using a cluster analysis based on patenting behaviour and comprises manufacturing, mining and quarrying; electricity, gas and water supply; construction; wholesale and retail trade; transport, storage and communication; real estate, renting and business activities; and other

Table 6 Estimated relative patent productivities, manufacturing and eight innovative industries: larger firms (50+ employees)
Manufacturing

(1) (2)
Eight innovative industries

(3)

(4)

\section{R\&D workers}

Joiners from patenting firms

\begin{tabular}{|c|c|c|c|c|}
\hline ... intraregional & $3.837 * *$ & $3.916 * *$ & $5.053 * * *$ & $5.114 * * *$ \\
\hline ... interregional & -1.511 & -1.861 & $3.330^{*}$ & $3.680 * *$ \\
\hline \multicolumn{5}{|l|}{... from non-patenting firms } \\
\hline$\ldots$ intraregional & 3.182 & 2.929 & 2.209 & 2.449 \\
\hline ... interregional & 1.169 & 0.679 & 0.124 & 0.287 \\
\hline \multicolumn{5}{|l|}{ Leavers to patenting firms } \\
\hline ... intraregional & 1.922 & 2.284 & 3.135 & 2.820 \\
\hline ... interregional & -3.078 & -4.384 & 3.869 & 3.202 \\
\hline \multicolumn{5}{|l|}{$\ldots$ to non-patenting firms } \\
\hline ... intraregional & -2.351 & -2.268 & -0.688 & -0.662 \\
\hline ... interregional & 2.176 & 1.755 & 1.489 & 1.599 \\
\hline Other joiners & 0.495 & 0.746 & 2.351 & 2.390 \\
\hline \multicolumn{5}{|l|}{ Graduates ... } \\
\hline $\begin{array}{l}\ldots \text { for firms with } \\
\text { pre-sample patents }\end{array}$ & -4.044 & -4.903 & -1.230 & -2.335 \\
\hline $\begin{array}{c}\ldots \text { for firms without } \\
\text { pre-sample patents }\end{array}$ & $-8.762 * *$ & $-9.748 * *$ & 2.067 & 1.757 \\
\hline Associate $\mathrm{R} \& \mathrm{D}$ workers & 0.780 & 0.513 & 0.631 & 0.614 \\
\hline Industry dummies & 1-digit NACE & 3-digit NACE & 1-digit NACE & 3-digit NACE \\
\hline Regional control variables & No & Yes & No & Yes \\
\hline
\end{tabular}

\section{Manufacturing}

(1)
2)

\footnotetext{
$* * *, * *$ and $*$ denote statistical significance at the 1, 5 and 10 percentage level, respectively. The group of eight industries is identified using a cluster analysis based on patenting behaviour and comprises manufacturing, mining and quarrying; electricity, gas and water supply; construction; wholesale and retail trade; transport, storage and communication; real estate; renting and business activities; and other

(itms (50+ employes)
}

Eight innovative industries

(3) (4)

\section{R\&D workers}

Joiners from patenting firms

$\begin{array}{lllll}\ldots \text { intraregional } & 1.172 & 0.055 & 3.511 & 1.867 \\ \ldots \text { interregional } & 3.195 & 1.552 & 3.417 & 1.257 \\ \ldots \text { from non-patenting firms } & & & & \\ \ldots \text { intraregional } & 3.318 & 2.383 & 5.404 * * * & 3.824 * * \\ \ldots \text { interregional } & 4.726^{*} & 4.279^{*} & 6.462^{* * *} & 4.846^{* *} \\ \begin{array}{l}\text { Leavers to patenting firms } \\ \ldots \text { intraregional }\end{array} & 1.283 & 0.974 & 2.372 & 1.104 \\ \ldots \text { interregional } & -0.072 & -1.205 & -1.879 & -2.742 \\ \ldots \text { to non-patenting firms } & & & & \\ \ldots \text { intraregional } & -1.390 & -0.529 & 0.511 & 1.167 \\ \ldots \text { interregional } & -3.137 * * & -2.237 * * & -4.224 * * * & -3.305^{* * *} \\ \text { Other joiners } & -1.069 & -0.153 & -0.812 & 0.226 \\ \text { Graduates ... } & & & & \\ \ldots \text { for firms with } & -1.773 & -6.802 & 1.996 & -1.215\end{array}$

(2)
) pre-sample patents 


\begin{tabular}{|c|c|c|c|c|}
\hline & \multicolumn{2}{|l|}{ Manufacturing } & \multicolumn{2}{|c|}{ Eight innovative industries } \\
\hline & (1) & (2) & (3) & (4) \\
\hline $\begin{array}{c}\ldots \text { for firms without } \\
\text { pre-sample patents }\end{array}$ & -1.810 & -1.075 & 3.099 & 3.097 \\
\hline Associate R\&D workers & 1.187 & 0.552 & 1.032 & 0.616 \\
\hline Industry dummies & 1-digit NACE & 3-digit NACE & 1-digit NACE & 3-digit NACE \\
\hline Regional control variables & No & Yes & No & Yes \\
\hline
\end{tabular}

Interacting graduates with a dummy variable for innovative firms in the pre-sample also failed to attain significance throughout the estimations. Hence, intrapreneurial capacities seem to be limited to a relatively small group of professions and skills where experience plays an important role.

Considering the geographic dimension in columns 3 and 4, intraregional joiners from patenting firms dominate even though some significance can also be attributed interregional joiners from patenting firms. As for leavers, no statistically significant effect could be detected, irrespective of geographical unit.

Regarding remaining controls, the results are as expected with regards to the innovation variables (total R\&D work force, pre-sample variables and patent dummies). No effect is reported for remaining labour mobility controls or capital stock. Basically, the results are in line with our hypotheses.

Turning to medium-sized and larger firms having at least 50 employees, the pattern looks different (Table 2) even though the overall effect is positive (column 1). However, the effect in this case is dominated by joiners from non-patenting firms, i.e. opposite to what we saw for small firms. This may seem counter-intuitive, but several explanations are conceivable. First, smaller firms tend to lack sufficient complementing R\&D resources, which combined with the new worker's inexperience from innovation activities might be a too big obstacle for innovation to occur. This is less likely for the larger firm. Second, joiners from non-innovating firms seem more likely to diverge in their knowledge as compared to joiners from innovating firms. Thus, heterogeneity may be exploited by larger firms due to higher absorptive capacity related to size. Hence, joiners from non-innovating firms could contribute to a more diversified knowledge base in innovating large firms, resulting in higher innovation activities.

We also note that R\&D workers who previously worked in innovative firms have different effects in smaller and larger firms' patent production. Smaller firms benefit from these joiners, while no effect can be detected for larger firms. One reason forwarded in the literature relates to what the employer is willing to do-the disagreement model of innovation and entry (Klepper and Thompson 2010)which causes R\&D workers to look for new opportunities outside their current employer. Joining a smaller innovative firm may give more room to pursue ideas rejected by previous employers. R\&D workers in innovative firms that lack this motive are more likely to be indifferent between the size of their new employer, and hence, we have a selection where workers with more innovative ambitions tend to go to smaller firms. Another plausible reason is that $R \& D$ workers experience of patenting processes simply carries a higher weight in the smaller firm as compared to larger firms.

We can however only hypothesize about these alleged reasons; the data does not allow us to dig deeper. In addition, we note that leavers to non-patenting firms exert a weak negative effect on innovation activities in the firms they left. Associate R\&D workers are also shown to have relatively weak but negative effects on innovation relative to stayers in some of the regressions, as is other joiners. Also, regional effects differ across the two groups of firms. For larger firms, both intraregional and interregional mobility matters, but again solely for joiners from non-patenting firms. As regards the 
remaining controls, they are basically in line with the results for smaller firms.

To summarize, the pattern that emerges for small and larger firm differs considerably, where small firms are shown to be more dependent on joiners from firms with ongoing innovative activities that are located in the region. Large firms on the other hand are not restricted to the region in which they operate and benefit more from joiners recruited from non-patenting firms.

\subsection{Regional control variables}

Neither the regional labour mobility variables nor the share of a region's workers with a completed tertiary education seem to have a significant impact on firms' innovative output according to the estimates in column 4 in Tables 1 and 2. Regional density, on the other hand, turns up with an unexpected but minor negative sign in the case of small firms, which suggests that more workers per square kilometre has a negative influence on innovation at the firm level. One explanation for this result could be that regional density is highly correlated with the regional dummies, making it hard to separate their individual effects on firms' innovativeness.

Finally, the positive and significant effect shown for the accessibility variable highlights the importance of controlling for spatial autocorrelation when estimating firm level patent production functions-firms located close to firms with high innovative output tend to be more innovative and vice versa.

\subsection{Relative patent productivities}

The estimated coefficients from the negative binomial regressions in Tables 1 and 2 enable us to derive the underlying structural parameters of the patent production function, i.e. to calculate the relative patent productivities ( $\gamma$ in Eq. (6)). Table 3 provides estimates of the relative patent productivities for our four baseline regression specifications for small firms.

Starting with column 2, joiners from patenting firms are on average 4.6 times more patent productive than stayers, while no effect was obtained for joiners from non-patenting firms. Thus, employing R\&D workers with experience from an innovating firm have not only a statistically significant effect on innovation, but the effect is also economically important for small firms. We also find that $R \& D$ workers leaving a firm to join a patenting firm yield quite strong effects on innovation; on average, this type of workers are 3.3 times as patent productive as stayers, albeit the significance level is much lower.

Next, when we distinguish between intraregional and interregional mobility of R\&D workers in columns 3 and 4 , we find that the positive effect can mainly be attributed to intraregional mobility and solely confined to joiners from patenting firms, while no effect could be observed for the other variables.

For large firms (Table 4), almost the opposite results are reported. Joiners from non-patenting firms, both intraregional and interregional, have the strongest impact on patent productivity, ranging between a factor 6.3 and 3.8 in the different regressions. A considerable sensitivity for leavers to non-patenting firms in other regions is also reported for medium-sized and large firms.

To test the robustness of our results, we have also performed the analysis on two different subsets of our data. The first subset is the manufacturing industry, and the second subset comprises the eight most innovative industries as identified by a cluster analysis. The results for small firms are presented in Table 5.

When we restrict the analysis to the manufacturing sector (columns 1 and 2 which are comparable to columns 3 and 4 in Table 3), most of the significance attained in the previous estimations remain, but the magnitudes of the coefficients are on a somewhat lower level. A similarly noteworthy result is that an influx of graduates is shown to have a relatively strong negative effect on patent productivity in manufacturing firms, suggesting that matching problems or that "training on the job" is required before competencies of graduates can be fully utilized.

When we instead look at the most innovative industries, a first observation is that they are composed of both industry and service sectors. Moreover, the results are very similar to those reported in Table 3 and if anything, more accentuated. The negative effects of graduates also disappear. Thus, mobility of R\&D 
workers exerts its strongest influence on the most innovative industries.

For larger firms (Table 6), and compared to the results reported in Table 4, the effects are considerably weaker for the manufacturing sector and on par with the previous results when examining the eight most innovative industries.

\subsection{Causality}

In the theoretical framework, we interpreted the causality relationship as going from labour mobility to knowledge flows and innovation, assuming that firms hire experienced workers from other firms to acquire human capital and external knowledge. However, we are aware there might be an endogeneity problem; is it labour mobility that stimulates innovation or the other way around?

We have attempted to avoid this problem in two ways. First, we have employed a one-year lag distribution on labour mobility. Second, we use the patent application as the dependent variable, which has the advantage of not being exposed to lengthy time delays, compared with granted patents. It seems unlikely that labour will be attracted by patent applications, given that the outcome is uncertain and could well be associated with higher risks for the employee.

Moreover, hiring employees is an active decision made by firm management. If the firm wants to become more innovative, it will search for and hire relevant $\mathrm{R} \& \mathrm{D}$ workers to help it achieve that goal. Hence, the logical timing of events runs from firm hiring $R \& D$ workers to innovation and not the other way around. Also, note that we are interested in the effect of mobile R\&D relevant workers. While innovation may cause firms to hire more or less workers, it is less likely to affect the category of workers which our empirical analysis is based upon. Given the arguments provided above, we claim that reverse causality should not be a problem in our empirical analysis.

\section{Conclusion}

Emanating from a theoretical framework proposed by Acs et al. (2009), we present an empirical analysis of the relationship between labour mobility, knowledge diffusion, firm size and firm innovation output. We distinguish between two subgroups of workers: R\&D workers and associate $R \& D$ workers to separate the effects of the mobility of knowledge workers which we define as intrapreneurs, i.e. conducive in creating innovations. By implementing a unique matched employer-employee dataset, which has been pooled with firm-level patent application data, we provide evidence that the mobility of knowledge (R\&D) workers has a strong positive and significant effect on firm innovativeness, but that the effects and channels through which these effect works differ between firms of different sizes.

We conclude that there are primarily forward knowledge flows (between receiving and sourcing firms) but that the existence of backward flows may exist for some industries and some firms. In addition, the geographical dimension of knowledge flows is important for innovation activities and dominated by intraregional labour mobility for smaller firms. For larger firms, also interregional flows have a significant influence on innovation. For the cohort of smaller firms, the effects of R\&D labour mobility are shown to be strongest when firms are already engaged in innovative activities (and again particularly so for the receiving firm). For larger firms, the opposite patterns prevail.

The results have important and highly relevant policy implications. Whereas previous analyses have shown that smaller firms are important contributors to radical innovations, our analysis provides evidence that they are dependent on inflows of R\&D workers from other innovating firms. Hence, labour flexibility policies are critically important for innovative activities. Moreover, the marked effect of intraregional mobility carries important policy implications at the regional as well as at the more aggregated levels. Removing obstacles and facilitating intraregional mobility may be a way to enhance cross-fertilization of knowledge and improve matching and strengthening spillovers from knowledge networks.

In the ongoing discussions regarding how to augment growth in large parts of Europe, flexibility of the labour market is attributed a strategically important role. Our results show that more flexible labour markets may not only be expected to lead to higher labour participation, higher productivity and better matching but may also be instrumental in promoting innovation and ultimately higher growth.

Acknowledgments Financial support is gratefully acknowledged from Marianne and Marcus Wallenberg Foundation. 


\section{Appendix}

Table 7 Variable descriptions

\begin{tabular}{|c|c|}
\hline Variable & Description \\
\hline Joiners & $\begin{array}{l}\mathrm{R} \& \mathrm{D} \text { workers who joined the firm between year } t-1 \text { and } t \text { and who } \\
\text { worked at another firm year } t-1 \text {, divided by the firm's total R\&D } \\
\text { workforce }^{\mathrm{a}}\end{array}$ \\
\hline Joiners from patenting firms & $\begin{array}{l}\text { Joiners who worked at a firm which applied for at least one patent during the } \\
\text { pre-sample period }^{\mathrm{b}}\end{array}$ \\
\hline Joiners from patenting firms, intraregional & $\begin{array}{l}\text { Joiners from patenting firms who worked at a firm located in the same } \\
\text { region year } t-1\end{array}$ \\
\hline Joiners from patenting firms, interregional & $\begin{array}{l}\text { Joiners from patenting firms who worked at a firm located in another region } \\
\text { year } t-1\end{array}$ \\
\hline Joiners from non-patenting firms & $\begin{array}{l}\text { Joiners who worked at a firm which did not apply for any patents during the } \\
\text { pre-sample period }\end{array}$ \\
\hline Joiners from non-patenting firms, intraregional & $\begin{array}{l}\text { Joiners from non-patenting firms who worked at a firm located in the same } \\
\text { region year } t-1\end{array}$ \\
\hline Joiners from non-patenting firms, interregional & $\begin{array}{l}\text { Joiners from non-patenting firms who worked at a firm located in another } \\
\text { region year } t-1\end{array}$ \\
\hline Leavers & $\begin{array}{l}\mathrm{R} \& \mathrm{D} \text { workers who left the firm between year } t-1 \text { and } t \text { and who are } \\
\text { working at another firm year } t \text {, divided by the firm's total R\&D } \\
\text { workforce }\end{array}$ \\
\hline Leavers to patenting firms & $\begin{array}{l}\text { Leavers who went to a firm which applied for at least one patent during the } \\
\text { pre-sample period }\end{array}$ \\
\hline Leavers to patenting firms, intraregional & $\begin{array}{l}\text { Leavers to patenting firms who went to a firm located in the same region } \\
\text { year } \mathrm{t}\end{array}$ \\
\hline Leavers to patenting firms, interregional & Leavers to patenting firms who went to a firm located in another region year $t$ \\
\hline Leavers to non-patenting firms & $\begin{array}{l}\text { Leavers who went to a firm which did not apply for any patents during the pre- } \\
\text { sample period }\end{array}$ \\
\hline Leavers to non-patenting firms, intraregional & $\begin{array}{l}\text { Leavers to non-patenting firms who went to a firm located in the same region } \\
\text { year } t\end{array}$ \\
\hline Leavers to non-patenting firms, interregional & $\begin{array}{l}\text { Leavers to non-patenting firms who went to a firm located in another region } \\
\text { year } t\end{array}$ \\
\hline Other joiners & $\begin{array}{l}\mathrm{R} \& \mathrm{D} \text { workers who joined the firm between year } t-1 \text { and } t \text { and whose } \\
\text { background is unknown, divided by the firm's total R\&D workforce }\end{array}$ \\
\hline Graduates & $\begin{array}{l}\mathrm{R} \& \mathrm{D} \text { workers who joined the firm between year } t-1 \text { and } t \text { and who graduated } \\
\text { from a university year } t-1 \text {, divided by the firm's total R\&D workforce }\end{array}$ \\
\hline $\begin{array}{l}\text { Interaction variable between graduates and a } \\
\text { dummy for firms with pre-sample patents }\end{array}$ & $\begin{array}{l}\text { Graduates multiplied by a dummy variable which indicates if the firm the } \\
\text { graduate starts to work for applied for a patent during the pre-sample period }\end{array}$ \\
\hline Associate R\&D workers & Associate R\&D workers, divided by the firm's total R\&D workforce \\
\hline Total R\&D work force, logarithm & The natural logarithm of the firm's total R\&D workforce \\
\hline Capital stock, logarithm & $\begin{array}{l}\text { The natural logarithm of the firm's capital stock, where the capital stock is } \\
\text { estimated by the perpetual inventory method with a constant depreciation } \\
\text { rate of } 5 \%\end{array}$ \\
\hline FE, logarithm & Natural logarithm of Blundell et al.’s (1995) pre-sample estimator \\
\hline FE, dummy & $\begin{array}{l}\text { A dummy variable indicating if the firm applied for at least one patent during } \\
\text { the pre-sample period }\end{array}$ \\
\hline Dummy patent $t-1$ & A dummy variable indicating if the firm applied for a patent year $t-1$ \\
\hline Dummy patent $t-2$ & A dummy variable indicating if the firm applied for a patent year $t-2$ \\
\hline
\end{tabular}


Table 7 (continued)

\begin{tabular}{ll}
\hline Variable & Description \\
\hline Labour mobility into the region & $\begin{array}{c}\text { Total number of employees in the region year t who worked in a firm located in } \\
\text { another region year } t-1 \text {, divided by the total number of workers in the region } \\
\text { year } t\end{array}$ \\
$\begin{array}{ll}\text { Total number of workers who left the region year } t-1 \text { to take a new job in } \\
\text { another region year } t \text {, divided by the total numbers of workers in the region } \\
\text { year } t\end{array}$ \\
$\begin{array}{l}\text { Total number of workers in the region year } t \text { who had switched employers within } \\
\text { the region between year } t-1 \text { and } t \text {, divided by the total number of workers in } \\
\text { the region year } t\end{array}$ \\
$\begin{array}{l}\text { Share of those employed in the region with a completed tertiary education } \\
\text { Number of people employed per square kilometre }\end{array}$ \\
$\begin{array}{l}\text { Nertiary education rate } \\
\text { Regional density }\end{array}$ \\
$\begin{array}{l}\text { Distance weighted sum of surrounding regions' number of patent applications. } \\
\text { Intended to control for potential spatial autocorrelation }\end{array}$ \\
Herfindahl index based on regional employment in 3-digit industries
\end{tabular}

${ }^{\mathrm{a}}$ The total R\&D workforce is defined as the sum of $\mathrm{R} \& \mathrm{D}$ workers and associate $\mathrm{R} \& \mathrm{D}$ workers

${ }^{\mathrm{b}}$ The pre-sample period covers the years 1987-2000

Table 8 Descriptive statistics

\begin{tabular}{|c|c|c|c|c|}
\hline Variable & Mean & Std. dev. & Min & Max \\
\hline Number of patents & 0.3572 & 12.50 & 0 & 1691 \\
\hline Patent $t-1$ & 0.4084 & 12.64 & 0 & 1426 \\
\hline Patent $t-2$ & 0.4627 & 13.82 & 0 & 1426 \\
\hline Dummy patent $t-1$ & 0.0337 & 0.18 & 0 & 1 \\
\hline Dummy patent $t-2$ & 0.0347 & 0.18 & 0 & 1 \\
\hline \multicolumn{5}{|l|}{ Worker shares } \\
\hline \multicolumn{5}{|l|}{$\mathrm{R} \& \mathrm{D}$ workers } \\
\hline \multicolumn{5}{|l|}{ Joiners ... } \\
\hline ... from patenting firms & 0.0104 & 0.08 & 0 & 1 \\
\hline ... intraregional & 0.0057 & 0.06 & 0 & 1 \\
\hline ... interregional & 0.0047 & 0.05 & 0 & 1 \\
\hline ... from non-patenting firms & 0.0405 & 0.16 & 0 & 1 \\
\hline ... intraregional & 0.0274 & 0.14 & 0 & 1 \\
\hline ... interregional & 0.0131 & 0.09 & 0 & 1 \\
\hline \multicolumn{5}{|l|}{ Leavers ... } \\
\hline$\ldots$ to patenting firms & 0.0088 & 0.08 & 0 & 9 \\
\hline$\ldots$ intraregional & 0.0048 & 0.06 & 0 & 8 \\
\hline ... interregional & 0.0040 & 0.05 & 0 & 2 \\
\hline$\ldots$ to non-patenting firms & 0.0298 & 0.15 & 0 & 9 \\
\hline ... intraregional & 0.0188 & 0.12 & 0 & 6 \\
\hline ... interregional & 0.0110 & 0.09 & 0 & 5 \\
\hline Graduates & 0.0056 & 0.04 & 0 & 1 \\
\hline Other joiners & 0.0167 & 0.11 & 0 & 1 \\
\hline
\end{tabular}


Table 8 (continued)

\begin{tabular}{|c|c|c|c|c|}
\hline Variable & Mean & Std. dev. & Min & Max \\
\hline Stayers & 0.5708 & 0.45 & 0 & 1 \\
\hline Associate $\mathrm{R} \& \mathrm{D}$ workers & 0.3561 & 0.44 & 0 & 1 \\
\hline \multicolumn{5}{|l|}{ Firm size and capital stock } \\
\hline Total employment & 79.8 & 449.9 & 1 & 19,817 \\
\hline R\&D relevant employment & 7.2 & 76.3 & 1 & 7427 \\
\hline Capital stock, millions SEK & 67.2 & 790.1 & 0 & 51,014 \\
\hline \multicolumn{5}{|l|}{ Pre-sample variables } \\
\hline Pre-sample patents (FE) & 0.00004 & 0.0008 & 0 & 0.1 \\
\hline Dummy, pre-sample patents & 0.0927 & 0.29 & 0 & 1 \\
\hline \multicolumn{5}{|l|}{ Industry dummies } \\
\hline Agriculture & 0.0098 & 0.10 & 0 & 1 \\
\hline Fishing & 0.00002 & 0.00 & 0 & 1 \\
\hline Mining and quarrying & 0.0009 & 0.03 & 0 & 1 \\
\hline Manufacturing & 0.1664 & 0.37 & 0 & 1 \\
\hline Electricity, gas and water supply & 0.0087 & 0.09 & 0 & 1 \\
\hline Construction & 0.0220 & 0.15 & 0 & 1 \\
\hline Wholesale and retail trade & 0.1318 & 0.34 & 0 & 1 \\
\hline Hotels and restaurants & 0.0017 & 0.04 & 0 & 1 \\
\hline Transport, storage and communication & 0.0170 & 0.13 & 0 & 1 \\
\hline Financial intermediation & 0.0015 & 0.04 & 0 & 1 \\
\hline Real estate, renting and business activities & 0.3801 & 0.49 & 0 & 1 \\
\hline Education & 0.0189 & 0.14 & 0 & 1 \\
\hline Health and social work & 0.2163 & 0.41 & 0 & 1 \\
\hline Other community, social and personal service & 0.0188 & 0.14 & 0 & 1 \\
\hline Other & 0.0061 & 0.01 & 0 & 1 \\
\hline \multicolumn{5}{|l|}{ Regional control variables } \\
\hline Labour mobility into the region & 0.001 & 0.005 & 0.000 & 0.099 \\
\hline Labour mobility out from the region & 0.045 & 0.123 & 0.000 & $2.059^{\mathrm{a}}$ \\
\hline Intraregional labour mobility & 0.010 & 0.019 & 0.000 & 0.343 \\
\hline Tertiary education rate & 0.070 & 0.048 & 0.009 & 0.274 \\
\hline Regional density (no. of employees per $\mathrm{km}^{2}$ ) & 9.240 & 12.664 & 0.036 & 67.845 \\
\hline Accessibility measure, logarithm & -2.924 & 3.885 & -25.164 & 2.376 \\
\hline Diversity & 0.127 & 0.026 & 0.083 & 0.257 \\
\hline
\end{tabular}

Regional control variables show statistics calculated across the 72 labour market regions

${ }^{a}$ In 2001, 1618 workers left the labour market region Pajala, while 768 workers remained in the region. Hence, the share of leavers this year is 1618 divided by 768 , which is equal to 2.059 
P. Braunerhjelm et al.

Table 9 Mean statistics, distributed on firm's innovative history

\begin{tabular}{|c|c|c|c|}
\hline Variable & All firms & $\begin{array}{l}\text { Firms with } \\
\text { pre-sample } \\
\text { patents }\end{array}$ & $\begin{array}{l}\text { Firms without } \\
\text { pre-sample } \\
\text { patents }\end{array}$ \\
\hline Number of patents & 0.3572 & 3.746 & 0.0108 \\
\hline Patent $t-1$ & 0.4084 & 4.0323 & 0.0121 \\
\hline Patent $t-2$ & 0.4627 & 4.3651 & 0.0125 \\
\hline Dummy patent $t-1$ & 0.0337 & 0.3134 & 0.0052 \\
\hline Dummy patent $t-2$ & 0.0347 & 0.3313 & 0.0044 \\
\hline \multicolumn{4}{|l|}{ Worker shares } \\
\hline \multicolumn{4}{|l|}{ R\&D workers } \\
\hline \multicolumn{4}{|l|}{ Joiners ... } \\
\hline$\ldots$ from patenting firms & 0.0104 & 0.0271 & 0.0087 \\
\hline ... intraregional & 0.0057 & 0.0151 & 0.0048 \\
\hline ... interregional & 0.0047 & 0.0120 & 0.0040 \\
\hline ... from non-patenting firms & 0.0405 & 0.0379 & 0.0407 \\
\hline ... intraregional & 0.0274 & 0.0207 & 0.0280 \\
\hline ... interregional & 0.0131 & 0.0172 & 0.0127 \\
\hline \multicolumn{4}{|l|}{ Leavers ... } \\
\hline$\ldots$ to patenting firms & 0.0088 & 0.0228 & 0.0073 \\
\hline ... intraregional & 0.0048 & 0.0130 & 0.0039 \\
\hline ... interregional & 0.0040 & 0.0098 & 0.0034 \\
\hline ... to non-patenting firms & 0.0298 & 0.0376 & 0.0290 \\
\hline ... intraregional & 0.0188 & 0.0196 & 0.0187 \\
\hline ... interregional & 0.0110 & 0.0179 & 0.0103 \\
\hline Graduates & 0.0056 & 0.0094 & 0.0052 \\
\hline Other joiners & 0.0167 & 0.0165 & 0.0167 \\
\hline Stayers & 0.5708 & 0.4448 & 0.5836 \\
\hline Associate $\mathrm{R} \& \mathrm{D}$ workers & 0.3561 & 0.4643 & 0.3450 \\
\hline \multicolumn{4}{|l|}{ Firm size and capital stock } \\
\hline Total employment & 79.8 & 326.4 & 54.6 \\
\hline $\mathrm{R} \& \mathrm{D}$ relevant employment & 7.2 & 33.1 & 4.6 \\
\hline Capital stock, millions SEK & 67.2 & 304.4 & 43.0 \\
\hline \multicolumn{4}{|l|}{ Pre-sample variables } \\
\hline Pre-sample patents (FE) & 0.00004 & 0.0004 & 0 \\
\hline Dummy, pre-sample patents & 0.0927 & 1.0000 & 0 \\
\hline \multicolumn{4}{|l|}{ Industry dummies } \\
\hline Agriculture & 0.0098 & 0.0028 & 0.0105 \\
\hline Fishing & 0.00002 & 0 & 0.00002 \\
\hline Mining and quarrying & 0.0009 & 0.0044 & 0.0006 \\
\hline Manufacturing & 0.1664 & 0.6044 & 0.1217 \\
\hline Electricity, gas and water supply & 0.0087 & 0.0069 & 0.0089 \\
\hline Construction & 0.0220 & 0.0171 & 0.0225 \\
\hline Wholesale and retail trade & 0.1318 & 0.1186 & 0.1331 \\
\hline Hotels and restaurants & 0.0017 & 0.0000 & 0.0019 \\
\hline Transport, storage and communication & 0.0170 & 0.0104 & 0.0177 \\
\hline Financial intermediation & 0.0015 & 0.0001 & 0.0016 \\
\hline Real estate, renting and business activities & 0.3801 & 0.2165 & 0.3968 \\
\hline
\end{tabular}


Table 9 (continued)

\begin{tabular}{llll}
\hline Variable & All firms & $\begin{array}{l}\text { Firms with } \\
\text { pre-sample } \\
\text { patents }\end{array}$ & $\begin{array}{l}\text { Firms without } \\
\text { pre-sample } \\
\text { patents }\end{array}$ \\
\hline $\begin{array}{l}\text { Education } \\
\text { Health and social work }\end{array}$ & 0.0189 & 0.0027 & 0.0206 \\
$\begin{array}{l}\text { Other community, social and } \\
\text { personal service }\end{array}$ & 0.2163 & 0.0053 & 0.2378 \\
Other & 0.0188 & 0.0061 & 0.0200 \\
\hline
\end{tabular}

Table 10 Descriptive statistics: small firms (0-49 employees)

\begin{tabular}{|c|c|c|c|c|}
\hline Variable & Mean & Std. dev. & Min & Max \\
\hline Number of patents & 0.0433 & 0.70 & 0 & 87 \\
\hline Patent $t-1$ & 0.0465 & 0.72 & 0 & 87 \\
\hline Patent $t-2$ & 0.0490 & 0.72 & 0 & 87 \\
\hline Dummy patent $t-1$ & 0.0155 & 0.12 & 0 & 1 \\
\hline Dummy patent $t-2$ & 0.0159 & 0.12 & 0 & 1 \\
\hline \multicolumn{5}{|l|}{ Worker shares } \\
\hline \multicolumn{5}{|l|}{ R\&D workers } \\
\hline \multicolumn{5}{|l|}{ Joiners ... } \\
\hline ... from patenting firms & 0.0086 & 0.08 & 0 & 1 \\
\hline ... intraregional & 0.0050 & 0.06 & 0 & 1 \\
\hline ... interregional & 0.0036 & 0.05 & 0 & 1 \\
\hline ... from non-patenting firms & 0.0382 & 0.17 & 0 & 1 \\
\hline$\ldots$ intraregional & 0.0271 & 0.14 & 0 & 1 \\
\hline$\ldots$ interregional & 0.0111 & 0.09 & 0 & 1 \\
\hline \multicolumn{5}{|l|}{ Leavers ... } \\
\hline ... to patenting firms & 0.0063 & 0.07 & 0 & 9 \\
\hline$\ldots$ intraregional & 0.0037 & 0.06 & 0 & 8 \\
\hline ... interregional & 0.0026 & 0.04 & 0 & 1 \\
\hline ... to non-patenting firms & 0.0243 & 0.14 & 0 & 5 \\
\hline ... intraregional & 0.0163 & 0.12 & 0 & 5 \\
\hline ... interregional & 0.0080 & 0.08 & 0 & 5 \\
\hline Graduates & 0.0049 & 0.04 & 0 & 1 \\
\hline Other joiners & 0.0163 & 0.11 & 0 & 1 \\
\hline Stayers & 0.6240 & 0.45 & 0 & 1 \\
\hline Associate $\mathrm{R} \& \mathrm{D}$ workers & 0.3081 & 0.44 & 0 & 1 \\
\hline \multicolumn{5}{|l|}{ Firm size and capital stock } \\
\hline Total employment & 10.3 & 11.9 & 1 & 49 \\
\hline $\mathrm{R} \& \mathrm{D}$ relevant employment & 2.1 & 2.6 & 1 & 37 \\
\hline Capital stock, millions SEK & 8.3 & 115.0 & 0 & 9683 \\
\hline \multicolumn{5}{|l|}{ Pre-sample variables } \\
\hline Pre-sample patents (FE) & 0.000004 & 0.00 & 0 & 0.002 \\
\hline Dummy, pre-sample patents & 0.0491 & 0.22 & 0 & 1 \\
\hline
\end{tabular}


P. Braunerhjelm et al.

Table 10 (continued)

\begin{tabular}{lllll}
\hline Variable & Mean & Std. dev. & Min & Max \\
\hline Industry dummies & & & 0 & 1 \\
Agriculture & 0.0099 & 0.10 & 0 & 1 \\
Fishing & 0.00003 & 0.01 & 0 & 1 \\
Mining and quarrying & 0.0003 & 0.02 & 0 & 1 \\
Manufacturing & 0.0935 & 0.29 & 0 & 1 \\
Electricity, gas and water supply & 0.0048 & 0.07 & 0 & 1 \\
Construction & 0.0166 & 0.13 & 0 & 1 \\
Wholesale and retail trade & 0.1315 & 0.34 & 0 & 1 \\
Hotels and restaurants & 0.0014 & 0.04 & 0 & 1 \\
Transport, storage and & 0.0095 & 0.10 & 0 & 1 \\
$\quad$ communication & & & 0 & 1 \\
Financial intermediation & 0.0017 & 0.04 & 0 & 1 \\
Real estate, renting and & 0.4286 & 0.49 & 0 & 1 \\
$\quad$ business activities & 0.0181 & 0.13 & 0 & 1 \\
Education & 0.2620 & 0.44 & 0 & 1 \\
Health and social work & 0.0167 & 0.13 & & \\
Other community, social & & & & \\
$\quad$ and personal service & 0.0053 & 0.07 & & \\
Other & 72,431 & & & \\
Number of observations & & & & 1 \\
\hline
\end{tabular}

Table 11 Mean statistics, distributed on firm's innovative history: small firms $(0-49$ employees)

\begin{tabular}{|c|c|c|c|}
\hline Variable & All firms & $\begin{array}{l}\text { Firms with } \\
\text { pre-sample } \\
\text { patents }\end{array}$ & $\begin{array}{l}\text { Firms without } \\
\text { pre-sample } \\
\text { patents }\end{array}$ \\
\hline Number of patents & 0.0433 & 0.7633 & 0.0061 \\
\hline Patent $t-1$ & 0.0465 & 0.8142 & 0.0058 \\
\hline Patent $t-2$ & 0.0490 & 0.8495 & 0.0057 \\
\hline Dummy patent $t-1$ & 0.0155 & 0.2570 & 0.0031 \\
\hline Dummy patent $t-2$ & 0.0159 & 0.2744 & 0.0025 \\
\hline \multicolumn{4}{|l|}{ Worker shares } \\
\hline \multicolumn{4}{|l|}{ R\&D workers } \\
\hline \multicolumn{4}{|l|}{ Joiners ... } \\
\hline ... from patenting firms & 0.0086 & 0.0306 & 0.0075 \\
\hline ... intraregional & 0.0050 & 0.0188 & 0.0043 \\
\hline ... interregional & 0.0036 & 0.0118 & 0.0032 \\
\hline ... from non-patenting firms & 0.0382 & 0.0417 & 0.0380 \\
\hline ... intraregional & 0.0271 & 0.0239 & 0.0273 \\
\hline ... interregional & 0.0111 & 0.0178 & 0.0107 \\
\hline \multicolumn{4}{|l|}{ Leavers ... } \\
\hline$\ldots$ to patenting firms & 0.0063 & 0.0228 & 0.0055 \\
\hline ... intraregional & 0.0037 & 0.0145 & 0.0031 \\
\hline ... interregional & 0.0026 & 0.0082 & 0.0023 \\
\hline ... to non-patenting firms & 0.0243 & 0.0376 & 0.0236 \\
\hline intraregional & 0.0163 & 0.0213 & 0.0160 \\
\hline
\end{tabular}


Table 11 (continued)

\begin{tabular}{|c|c|c|c|}
\hline Variable & All firms & $\begin{array}{l}\text { Firms with } \\
\text { pre-sample } \\
\text { patents }\end{array}$ & $\begin{array}{l}\text { Firms without } \\
\text { pre-sample } \\
\text { patents }\end{array}$ \\
\hline ... interregional & 0.0080 & 0.0163 & 0.0075 \\
\hline Graduates & 0.0049 & 0.0110 & 0.0046 \\
\hline Other joiners & 0.0163 & 0.0194 & 0.0161 \\
\hline Stayers & 0.6240 & 0.4997 & 0.6304 \\
\hline Associate $\mathrm{R} \& \mathrm{D}$ workers & 0.3081 & 0.3976 & 0.3034 \\
\hline \multicolumn{4}{|l|}{ Firm size and capital stock } \\
\hline Total employment & 10.3 & 20.8 & 9.7 \\
\hline $\mathrm{R} \& \mathrm{D}$ relevant employment & 2.1 & 3.3 & 2.0 \\
\hline Capital stock, millions SEK & 8.3 & 11.8 & 8.1 \\
\hline \multicolumn{4}{|l|}{ Pre-sample variables } \\
\hline Pre-sample patents (FE) & 0.000004 & 0.0001 & 0 \\
\hline Dummy, pre-sample patents & 0.0491 & 1 & 0 \\
\hline \multicolumn{4}{|l|}{ Industry dummies } \\
\hline Agriculture & 0.0099 & 0.0062 & 0.0101 \\
\hline Fishing & 0.00003 & 0 & 0.00003 \\
\hline Mining and quarrying & 0.0003 & 0.0006 & 0.0003 \\
\hline Manufacturing & 0.0935 & 0.4023 & 0.0775 \\
\hline Electricity, gas and water supply & 0.0048 & 0.0017 & 0.0050 \\
\hline Construction & 0.0166 & 0.0107 & 0.0169 \\
\hline Wholesale and retail trade & 0.1315 & 0.1875 & 0.1286 \\
\hline Hotels and restaurants & 0.0014 & 0.0000 & 0.0015 \\
\hline $\begin{array}{l}\text { Transport, storage and } \\
\text { communication }\end{array}$ & 0.0095 & 0.0028 & 0.0098 \\
\hline Financial intermediation & 0.0017 & 0.0003 & 0.0018 \\
\hline $\begin{array}{l}\text { Real estate, renting and } \\
\text { business activities }\end{array}$ & 0.4286 & 0.3669 & 0.4318 \\
\hline Education & 0.0181 & 0.0039 & 0.0189 \\
\hline Health and social work & 0.2620 & 0.0104 & 0.2750 \\
\hline $\begin{array}{l}\text { Other community, social and } \\
\text { personal service }\end{array}$ & 0.0167 & 0.0011 & 0.0175 \\
\hline Other & 0.0053 & 0.0056 & 0.0053 \\
\hline Number of observations & 72,431 & 3557 & 68,874 \\
\hline
\end{tabular}


P. Braunerhjelm et al.

Table 12 Descriptive statistics: larger firms (50+ employees)

\begin{tabular}{llllc}
\hline Variable & Mean & Std. dev. & Min & Max \\
\hline Number of patents & 1.5391 & 27.21 & 0 & 1691 \\
Patent $t-1$ & 1.6895 & 26.85 & 0 & 1426 \\
Patent $t-2$ & 1.8416 & 28.69 & 0 & 1426 \\
Dummy patent $t-1$ & 0.1023 & 0.30 & 0 & 1 \\
Dummy patent $t-2$ & 0.1055 & 0.31 & 0 & 1
\end{tabular}

Worker shares

R\&D workers

Joiners ...

... from patenting firms

... intraregional

... interregional

... from non-patenting firms

... intraregional

... interregional

$\begin{array}{llll}0.0173 & 0.08 & 0 & 1 \\ 0.0086 & 0.06 & 0 & 1 \\ 0.0087 & 0.06 & 0 & 1 \\ 0.0491 & 0.15 & 0 & 1 \\ 0.0283 & 0.11 & 0 & 1 \\ 0.0207 & 0.10 & 0 & 1\end{array}$

Leavers ...

... to patenting firms

... intraregional

... interregional

... to non-patenting firms

... intraregional

... interregional

Graduates

Other joiners

Stayers

Associate R\&D workers

Firm size and capital stock

Total employment

R\&D relevant employment

Capital stock, millions SEK

Pre-sample variables

Pre-sample patents (FE)

Dummy, pre-sample patents

Industry dummies

Agriculture

Fishing

Mining and quarrying

Manufacturing

Electricity, gas and water supply

Construction

$\begin{array}{llll}0.0180 & 0.09 & 0 & 2\end{array}$

$\begin{array}{llll}0.0088 & 0.06 & 0 & 2\end{array}$

$\begin{array}{llll}0.0092 & 0.07 & 0 & 2\end{array}$

$\begin{array}{llll}0.0507 & 0.19 & 0 & 9\end{array}$

$\begin{array}{llll}0.0283 & 0.14 & 0 & 6\end{array}$

$\begin{array}{llll}0.0224 & 0.11 & 0 & 4\end{array}$

$\begin{array}{llll}0.0082 & 0.04 & 0 & 1\end{array}$

$\begin{array}{llll}0.0181 & 0.09 & 0 & 1\end{array}$

$\begin{array}{llll}0.3704 & 0.36 & 0 & 1\end{array}$

$\begin{array}{llll}0.5369 & 0.39 & 0 & 1\end{array}$

$\begin{array}{llll}341.6 & 936.7 & 50 & 19,817\end{array}$

$\begin{array}{llll}26.5 & 165.2 & 1 & 7427\end{array}$

$\begin{array}{llll}289.2 & 1692 & 0 & 51,013\end{array}$

$\begin{array}{llll}0.0002 & 0.002 & 0 & 0.1\end{array}$

$\begin{array}{llll}0.2570 & 0.44 & 0 & 1\end{array}$

$\begin{array}{llll}0.0090 & 0.09 & 0 & 1\end{array}$

$\begin{array}{llll}0.0000 & 0.00 & 0 & 0\end{array}$

$\begin{array}{llll}0.0034 & 0.06 & 0 & 1\end{array}$

$\begin{array}{llll}0.4412 & 0.50 & 0 & 1\end{array}$

$\begin{array}{llll}0.0233 & 0.15 & 0 & 1\end{array}$

$\begin{array}{llll}0.0424 & 0.20 & 0 & 1\end{array}$

Wholesale and retail trade

$0.1328 \quad 0.34$

$0.0029 \quad 0.05$

$0.0455 \quad 0.21$

$0.0007 \quad 0.03$

$0.1972 \quad 0.40$

$0.0219 \quad 0.15$

9,817
427
1,013

1
Hotels and restaurants

Transport, storage and communication

Financial intermediation

Real estate, renting and business activities

Education 
Table 12 (continued)

\begin{tabular}{llllc}
\hline Variable & Mean & Std. dev. & Min & Max \\
\hline Health and social work & 0.0440 & 0.21 & 0 & 1 \\
Other community, social and personal service & 0.0267 & 0.16 & 0 & 1 \\
Other & 0.0090 & 0.09 & 0 & 1 \\
Number of observations & 19,237 & & & \\
\hline
\end{tabular}

Table 13 Mean statistics, distributed on firm's innovative history: larger firms $(50+$ employees)

\begin{tabular}{|c|c|c|c|}
\hline Variable & All firms & $\begin{array}{l}\text { Firms with } \\
\text { pre-sample } \\
\text { patents }\end{array}$ & $\begin{array}{l}\text { Firms without } \\
\text { pre-sample } \\
\text { patents }\end{array}$ \\
\hline Number of patents & 1.5391 & 5.8934 & 0.0334 \\
\hline Patent $t-1$ & 1.6895 & 6.1576 & 0.0408 \\
\hline Patent $t-2$ & 1.8416 & 6.5320 & 0.0424 \\
\hline Dummy patent $t-1$ & 0.1023 & 0.3540 & 0.0153 \\
\hline Dummy patent $t-2$ & 0.1055 & 0.3722 & 0.0133 \\
\hline \multicolumn{4}{|l|}{ Worker shares } \\
\hline \multicolumn{4}{|l|}{ R\&D workers } \\
\hline \multicolumn{4}{|l|}{ Joiners ... } \\
\hline ... from patenting firms & 0.0173 & 0.0246 & 0.0148 \\
\hline ... intraregional & 0.0086 & 0.0125 & 0.0072 \\
\hline ... interregional & 0.0087 & 0.0121 & 0.0076 \\
\hline ... from non-patenting firms & 0.0491 & 0.0352 & 0.0539 \\
\hline ... intraregional & 0.0283 & 0.0185 & 0.0317 \\
\hline ... interregional & 0.0207 & 0.0167 & 0.0221 \\
\hline \multicolumn{4}{|l|}{ Leavers ... } \\
\hline ... to patenting firms & 0.0180 & 0.0228 & 0.0163 \\
\hline$\ldots$ intraregional & 0.0088 & 0.0119 & 0.0077 \\
\hline ... interregional & 0.0092 & 0.0109 & 0.0086 \\
\hline ... to non-patenting firms & 0.0507 & 0.0375 & 0.0552 \\
\hline ... intraregional & 0.0283 & 0.0185 & 0.0317 \\
\hline ... interregional & 0.0224 & 0.0191 & 0.0235 \\
\hline Graduates & 0.0082 & 0.0083 & 0.0081 \\
\hline Other joiners & 0.0181 & 0.0143 & 0.0194 \\
\hline Stayers & 0.3704 & 0.4054 & 0.3583 \\
\hline Associate $\mathrm{R} \& \mathrm{D}$ workers & 0.5369 & 0.5123 & 0.5455 \\
\hline \multicolumn{4}{|l|}{ Firm size and capital stock } \\
\hline Total employment & 341.6 & 546.4 & 270.8 \\
\hline R\&D relevant employment & 26.5 & 54.5 & 16.9 \\
\hline Capital stock, millions SEK & 289.2 & 515.0 & 211.1 \\
\hline \multicolumn{4}{|l|}{ Pre-sample variables } \\
\hline Pre-sample patents (FE) & 0.0002 & 0.0006 & 0.0000 \\
\hline Dummy, pre-sample patents & 0.2570 & 1.0000 & 0.0000 \\
\hline \multicolumn{4}{|l|}{ Industry dummies } \\
\hline Agriculture & 0.0090 & 0.0004 & 0.0120 \\
\hline
\end{tabular}


Table 13 (continued)

\begin{tabular}{llll}
\hline Variable & All firms & $\begin{array}{l}\text { Firms with } \\
\text { pre-sample } \\
\text { patents }\end{array}$ & $\begin{array}{l}\text { Firms without } \\
\text { pre-sample } \\
\text { patents }\end{array}$ \\
\hline Fishing & 0.0000 & 0.0000 & 0.0000 \\
Mining and quarrying & 0.0034 & 0.0071 & 0.0021 \\
Manufacturing & 0.4412 & 0.7497 & 0.3345 \\
Electricity, gas and water supply & 0.0233 & 0.0107 & 0.0276 \\
Construction & 0.0424 & 0.0216 & 0.0495 \\
Wholesale and retail trade & 0.1328 & 0.0690 & 0.1548 \\
Hotels and restaurants & 0.0029 & 0.0000 & 0.0039 \\
Transport, storage and communication & 0.0455 & 0.0158 & 0.0558 \\
Financial intermediation & 0.0007 & 0.0000 & 0.0010 \\
Real estate, renting and business activities & 0.1972 & 0.1082 & 0.2279 \\
Education & 0.0219 & 0.0018 & 0.0288 \\
Health and social work & 0.0440 & 0.0016 & 0.0587 \\
Other community, social and personal service & 0.0267 & 0.0097 & 0.0325 \\
Other & 0.0090 & 0.0042 & 0.0106 \\
Number of observations & 19,237 & 4943 & 14,294 \\
\hline
\end{tabular}

Open Access This article is distributed under the terms of the Creative Commons Attribution 4.0 International License (http:// creativecommons.org/licenses/by/4.0/), which permits unrestricted use, distribution, and reproduction in any medium, provided you give appropriate credit to the original author(s) and the source, provide a link to the Creative Commons license, and indicate if changes were made.

\section{References}

Acs, Z., \& Audretsch, D. (1988). Innovation in large and small firms: an empirical analysis. American Economic Review, 78(4), 678-690.

Acs, Z., \& Audretsch, D. (1990). Innovation and small firms. Cambridge: MIT Press.

Acs, Z., Braunerhjelm, P., Audretsch, D., \& Carlsson, B. (2009). The knowledge spillover theory of entrepreneurship. Small Business Economics, 32(1), 15-30. https://doi.org/10.1007 /s11187-008-9157-3.

Aghion, P., \& Howitt, P. (1998). Endogenous growth theory. Cambridge, MA: MIT Press.

Aghion, P., \& Howitt, P. (2009). The economics of growth, Cambridge (Ma.) and London: MIT University Press.

Agrawal, A., \& Cockburn, I. (2003). The anchor tenant hypothesis: exploring the role of large, local, R\&D-intensive firms in regional innovation systems. International Journal of Industrial Organization, 21(9), 1227-1253. https://doi. org/10.1016/S0167-7187(03)00081-X.
Agrawal, A., Cockburn, I., \& McHale, J. (2006). Gone but not forgotten: knowledge flows, labor mobility, and enduring social relationships. Journal of Economic Geography, 6(5), 571-591. https://doi.org/10.1093 /jeg/lb1016.

Alcacer, J., \& Gittelman, M. (2006). Patent citations as a measure of knowledge flows: the influence of examiner citations. Review of Economics and Statistics, 88(4), 774-779. https://doi.org/10.1162/rest.88.4.774.

Aldrich, H., \& Auster, E. (1990). Even dwarfs started small: liabilities of age and size and their strategic implications. In B. Staw \& L. Cummings (Eds.), The Evolution and Adaptation of Organizations. Greenwich, CT: JAI Press.

Almeida, P. (1999). Semiconductor startups and the exploration of new technological territory. In Z. J. Acs (Ed.), Are Small Firms Important? Their Role and Impact. Boston, M.A: Kluwer Academic Publishers.

Almeida, P., \& Kogut, B. (1997). The exploration of technological diversity and the geographic localization of innovation. Small Business Economics, 9(1), 21-31. https://doi.org/10.1023 /A:1007995512597.

Almeida, P., \& Kogut, B. (1999). Localization of knowledge and the mobility of engineers in regional networks. Management Science, 45(7), 905-917. https://doi.org/10.1287 /mnsc.45.7.905.

Andersson, M., \& Thulin, P. (2008). Globalisering, arbetskraftens rörlighet och produktivitet. Research report 23, Swedish Globalization Council.

Andersson, M., Gråsjö, U., \& Karlsson, C. (2007). Human capital and productivity in a spatial economic system. Annals of Economics and Statistics, 87(88), 125-143. https://doi. org/10.2307/27650045. 
Audretsch, D. B., \& Feldman, M. P. (1996). R\&D spillovers and the geography of innovation and production. American Economic Review, 86(3), 630-640.

Baldwin, J.R. (1995). Innovation: the key to success in small firms. Statistics Canada Working Paper 76.

Baldwin, J. R., \& Johnson, J. (1999). Entry, innovation and firm growth. In Z. J. Acs (Ed.), Are Small Firms Important? Their Role and Impact. Boston, M.A: Kluwer Academic Publishers.

Balsvik, R. (2011). Is labor mobility a channel for spillovers from multinationals? Evidence from Norwegian manufacturing. The Review of Economics and Statistics, 93(1), 285-297. https://doi.org/10.1162/REST_a_0006.

Bassanini, A., \& Ernst, E. (2002). Labour market institutions, product market regulation, and innovation: cross-country evidence. OECD Economics Department, Working Papers, No. 316, OECD Publishing.

Baumol, W. (2004). Entrepreneurial enterprises, large established firms and other components of the free-market growth machine. Small Business Economics, 23(1), 9-21. https://doi. org/10.1023/B:SBEJ.0000026057.47641.a6.

Bessen, J., \& Maskin, E. (2009). Sequential innovation, patents, and imitation. RAND Journal of Economics, 40(4), 611-635. https://doi.org/10.1111/j.1756-2171.2009.00081.x.

Blundell, R., Griffith, R., \& Van Reenen, J. (1995). Dynamic count data models of technological innovation. The Economic Journal, 105(429), 333-344.

Braunerhjelm, P. (2011). Entrepreneurship, innovation and economic growth: interdependencies, irregularities and regularities. In D. B. Audretsch, O. Falck, \& S. Heblich (Eds.), Handbook of innovation and entrepreneurship. Cheltenham, UK and Northampton, MA: Edward Elgar.

Braunerhjelm, P., Ding, D., \& Thulin, P. (2014). Does labor mobility foster innovation? Evidence from Sweden. In Working paper 30. Swedish Entrepreneurship: Forum.

Breschi, S., \& Lissoni, F. (2005). Cross-firm inventors and social networks: localized knowledge spillovers revisited. Annales d'Economie et de Statistique, 79/80, 189-209. https://doi. org/10.2307/20777575.

Breschi, S., \& Lissoni, F. (2009). Mobility of skilled workers and co-invention networks: an anatomy of localized knowledge flows. Journal of Economic Geography, 9(4), 439-468. https://doi.org/10.1093/jeg/lbp008.

Cassiman, B., Veugelers, R., \& Arts, S. (2011). Tracing the effect of links between science and industry: the role of researcher interaction and mobility between firms and research organizations. IESE working paper.

Christensen, C. M. (1997). The innovator's dilemma: when new technologies cause great firms to fail. Boston. MA: Harvard Business School Press.

Corredoira, R., \& Rosenkopf, L. (2010). Should auld acquaintance be forgot? The reverse transfer of knowledge through mobility ties. Strategic Management Journal, 31(2), 159-181. https://doi.org/10.1002/smj.803.

Crane, D. (1969). Social structure in a group of scientists: a test of the 'invisible college' hypothesis. American Sociological Review, 34(3), 335-352.

Ejermo, O., \& Jung, T. (2014). Demographic patterns and trends in patenting: gender, age, and education of inventors. Technological Forecasting and Social Change, 86, 110124. https://doi.org/10.1016/j.techfore.2013.08.023.
Ejsing, A., Kaiser, U., Kongsted, H., \& Laursen, K. (2013). The role of university scientist mobility for industrial innovation. IZA discussion paper7470. http://ftp.iza.org/dp7470.pdf.

Essletzbichler, J., \& Rigby, D. (2005). Technological evolution as creative destruction of process heterogeneity: evidence from US plant-level data. Economic Systems Research, 17(1), 2545. https://doi.org/10.1080/09535310500034168.

Fallick, B., Fleischman, C. A., \& Rebitzer, J. B. (2006). Jobhopping in Silicon Valley: some evidence concerning the microfoundations of a high-technology cluster. The Review of Economics and Statistics, 88(3), 472-481. https://doi. org/10.1162/rest.88.3.472.

Fosfuri, A., \& Rønde, T. (2004). High-tech clusters, technology spillovers, and trade secret Laws. International Journal of Industrial Organization, 22(1), 45-65. https://doi. org/10.1016/S0167-7187(03)00123-1.

Franco, A. M., \& Mitchell, M. F. (2008). Covenants not to compete, labor mobility, and industry dynamics. Journal of Economics and Management Strategy, 17(3), 581-606. https://doi.org/10.1111/j.1530-9134.2008.00187.x.

Freel, M. S. (2003). Sectoral patterns of small firm innovation, networking and proximity. Research Policy, 32(5), 751-770. https://doi.org/10.1016/S0048-7333(02)00084-7.

Gans, J. S., \& Stern, S. (2003). The product market and the market for "ideas": commercialization strategies for technology entrepreneurs. Research Policy, 32(2), 333-350. https://doi. org/10.1016/S0048-7333(02)00103-8.

Griliches, Z. (1967). Production functions in manufacturing: some preliminary results. In M. Brown (Ed.), The Theory and Empirical Analysis of Production (pp. 275-340). New York and London: NBER Book Series Studies in Income and Wealth. Columbia University Press.

Griliches, Z. (1990). Patent statistics as economic indicators: a survey. Journal of Economic Literature, 28(4), 1661-1707.

Hall, B.H. (2011). Using productivity as an innovation indicator. Report for the High-Level Panel on Measuring Innovation, DG Research, European Commission.

Hoisl, K. (2007). Tracing mobile inventors - the causality between inventor mobility and inventor productivity. Research Policy, 36(5), 619-636. https://doi.org/10.1016/j. respol.2007.01.009.

Hoti, S., McAleer, M., \& Slottje, D. (2006). Intellectual property litigation in the USA. Journal of Economic Surveys, 20(4), 715-729. https://doi.org/10.1111/j.1467-6419.2006.00264.x.

Ichniowski, C., \& Shaw, K. (1995). Old dogs and new tricks: determinants of the adoption of productivity-enhancing work practices. In M. Baily, P. Reiss, \& C. Winston (Eds.), (pp. 165). Washington, DC: Brookings Papers on Economic Activity. Brookings Institute.

Jaffe, A.B., Trajtenberg, M., \& Henderson, R. (1992). Geographic localization of knowledge spillovers as evidenced by patent citations. NBER Working Paper No. 3993.

Kaiser, U., Kongsted, H.C., \& Rønde, T. (2011). Labor mobility, social network effects, and innovative activity. IZA Discussion Paper No. 5654. Available at SSRN: http://ssrn. com/abstract $=1820945^{\circ}$.

Kaiser, U., Kongsted, H. C., \& Rønde, T. (2015). Does the mobility of R\&D labor increase innovation? Journal of Economic Behavior \& Organization, 110, 91-105. https://doi. org/10.1016/j.jebo.2014.12.012. 
Kim, J., \& Marschke, G. (2005). Labor mobility of scientists, technological diffusion, and the firm's patenting decision. RAND Journal of Economics, 36(2), 298-317.

Klepper, S., \& Thompson, P. (2010). Disagreements and intraindustry spinoffs. International Journal of Industrial Organization, 28(5), 526-538. https://doi.org/10.1016/j. ijindorg.2010.01.002.

Mansfield, E. (1985). How rapidly does new industrial technology leak out? The Journal of Industrial Economics, 34(2), 217223. https://doi.org/10.2307/2098683.

Marx, M., Strumsky, D., \& Fleming, L. (2009). Mobility, skills, and the Michigan non-compete experiment. Management Science, 55(6), 875-889. https://doi.org/10.1287 /mnsc. 1080.0985 .

Nicoletti, G., \& Scarpetta, S. (2003). Regulation, productivity and growth: OECD evidence. Economic Policy, 18(36), 11-72.

Oettl, A., \& Agrawal, A. (2008). International labor mobility and knowledge flow externalities. Journal of International Business Studies, 39(8), 1242-1260. https://doi.org/10.1057 /palgrave.jibs. 8400358 .

Pakes, A., \& Nitzan, S. (1983). Optimal contracts for research personnel, research employment and the establishment of 'rival' enterprises. Journal of Labor Economics, 1(4), 345365. https://doi.org/10.1086/298017.

Parrotta, P., \& Pozzoli, D. (2012). The effect of learning by hiring on productivity. RAND Journal of Economics, 43(1), 167185. https://doi.org/10.1111/j.1756-2171.2012.00161.x.

Powell, W. W., Koput, K. W., \& Smith-Doerr, L. (1996). Interorganizational collaboration and the locus of innovation: networks of learning in biotechnology. Administrative Science Quarterly, 41(1), 116-145.

Romer, P. M. (1990). Endogenous technological change. The Journal of Political Economy, 98(5), S71-S102.

Rosenkopf, L., \& Almeida, P. (2003). Overcoming local search through alliances and mobility. Management Science, 49(6), 751-766. https://doi.org/10.1287/mnsc.49.6.751.16026.

Rothwell, R., \& Zegveld, W. (1982). Innovation and the small and medium sized firm. London: Pinter.

Samila, S., \& Sorenson, O. (2011). Noncompete covenants: incentives to innovate or impediments to growth. Management
Science, 57(3), 425-438. https://doi.org/10.1287 /mnsc.1100.1280.

Saxenian, A. (1994). Regional advantage: culture and competition in Silicon Valley and Route 128. Cambridge, Massachusetts: Harvard University Press.

Scarpetta, S., \& Tressel, T. (2004). Boosting productivity via innovation and adoption of new technologies: any role for labor market institutions? World Bank Policy Research Working Paper 3273.

Shane, S. (2000). Prior knowledge and the discovery of entrepreneurial opportunities. Organization Science, 11, 448-469. https://doi.org/10.1287/orsc.11.4.448.14602.

Song, J., Almeida, P., \& Wu, G. (2003). Learning-by-hiring: when is mobility more likely to facilitate interfirm knowledge transfer? Management Science, 49(4), 351-365. https://doi. org/10.1287/mnsc.49.4.351.14429.

Thompson, P., \& Fox-Kean, M. (2005). Patent citations and the geography of knowledge spillovers: a reassessment. American Economic Review, 95(1), 450-460. https://doi. org/10.1257/0002828053828509.

Topel, R., \& Ward, P. (1992). Job mobility and the careers of young men. The Quarterly Journal of Economics, 107, 429479.

Vilalta-Bufí, M. (2008). Inter-firm labor mobility and knowledge diffusion: a theoretical approach. Document de Treball, de La Facultat d'Economica I Empresa, Universitat de Barcelona, 2008.

Zhou, J., Shin, S. J., Brass, D. J., Choi, J., \& Zhang, Z. X. (2009). Social networks, personal values, and creativity: evidence for curvilinear and interaction effects. Journal of Applied Psychology, 94(6), 1544-1552.

Zhou, H., Dekker, R., \& Kleinknecht, A. (2011). Flexible labor and innovation performance: evidence from longitudinal firm-level data. Industrial and Corporate Change, 20(3), 941-968. https://doi.org/10.1093/icc/dtr013.

Zucker, L. G., Darby, M. R., \& Brewer, M. B. (1998). Intellectual human capital and the birth of U.S. biotechnology enterprises. American Economic Review, 88(1), 290-306. 